\title{
Stratigraphy, sedimentology and structure of the Oak Bay and Waweig formations, Mascarene Basin: implications for the paleotectonic evolution of southwestern New Brunswick
}

\author{
L.R. Fyffe ${ }^{1}$, R.K. Pickerill ${ }^{2}$, and P. Stringer ${ }^{2}$ \\ ${ }^{1}$ New Brunswick Department of Natural Resources and Energy, Geological Surveys Branch, P.O. Box 6000, \\ Fredericton, New Brunswick E3B 5H1,Canada \\ ${ }^{2}$ Department of Geology, University of New Brunswick, P.O. Box 4400, Fredericton, New \\ Brunswick E3B 5A3, Canada
}

Date Received: June 25, 1998

Date Accepted: February 1, 1999

\begin{abstract}
The northwestern margin of the Mascarene Basin is preserved within a southeasterly dipping homocline in the Oak Bay area of southwestern New Brunswick. The Mascarene Group in this area comprises up to $600 \mathrm{~m}$ of massive, resedimented conglomerate of the Oak Bay Formation and approximately $4200 \mathrm{~m}$ of volcanic and resedimented volcaniclastic and siliciclastic sandstone and mudstone of the conformably overlying Waweig Formation. The Waweig Formation is formally subdivided into three members: a lower volcaniclastic- and felsic volcanic-dominated Campbell Point Member $(\sim 600 \mathrm{~m}$ thick), a medial grey to black shale- and mafic volcanic-dominated Sawyer Brook Member ( 300 to $600 \mathrm{~m}$ thick), and an upper siliciclastic-dominated Simpson Corner Member with minor associated volcanic rocks $(\sim 3000 \mathrm{~m}$ thick). Five lithofacies recognized in the well-exposed Campbell Point Member include: (i) bedded tuffaceous sandstone facies, (ii) chaotic tuffaceous sandstone facies, (iii) waterlain pyroclastic facies, (iv) medium- to thick-bedded sandstone facies, and ( $v$ ) thin-bedded mudstone facies, all of which are products of sediment gravity flows. The massive conglomerates of the Oak Bay Formation were deposited as debris flows contemporaneous with faulting along the margin of the basin. Strata within the homocline possess a pervasive $\mathrm{S}_{1}$ cleavage oriented approximately $35^{\circ}$ oblique to bedding and a locally developed $\mathrm{S}_{2}$ cleavage; minor folds are rare and folds related to $\mathrm{S}_{1}$ are absent.

Correlation with a more complete Siluro-Devonian sequence in an adjacent fault block in Maine suggests that the Oak Bay and Waweig formations are Late Silurian (Ludlovian-Pridolian). The volcanic centres in Maine were potential sources of much of the epiclastic and pyroclastic detritus in the Waweig Formation. Distinctive stratigraphic sections in more highly deformed fault blocks farther to the southeast attest to the composite architecture of the Mascarene Basin. Existing paleontological evidence may indicate that subsidence of these blocks occurred progressively later to the northwest as a result of sequential downfaulting.

Consideration of the regional relationships between the Mascarene Basin with respect to the St. Croix Terrane and Fredericton Trough to the northwest and the New River Terrane to the southeast suggests that the basin developed by backarc rifting from the Silurian to Early Devonian and was flanked by a Late Ordovician to Silurian volcanic arc (Kingston Arc) to the southeast.
\end{abstract}

Dans la région d 'Oak Bay au sud-ouest du Nouveau Brunswick, la marge nord-ouest du bassin Mascarene est préservée dans un homoclinal inclinée vers le sud-est. Dans cette zone, le groupe de Mascarene comprend jusqu'à $600 \mathrm{~m}$ de conglomérat massif, re-sédimenté provenant de la Formation d 'Oak Bay et d'approximativement $4200 \mathrm{~m}$ de roche volcanique en plus de grès et de roche argileuse re-sédimenté volcaniclastique et siliciclastique dérivant du recouvrement de la formation Waweig. La formation de Waweig est formellement subdivisée en trois membres: Membre de Campbell Point, un volcaniclastique inférieur avec une dominance volcanique felsique ( $600 \mathrm{~m}$ d'épaisseur), un Membre du Ruisseau Sawyer, un schiste gris médial au noir avec une dominance volcanique mafique ( 300 à $600 \mathrm{~m}$ d'épaisseur), et un Membre de Simpson Corner, dominé par un siliciclastique supérieur associée de faible roche volcanique ( $3000 \mathrm{~m}$ d'épaisseur). Cinq faciès suffisamment exposé ont été identifiés dans le Membre de Campbell Point: (i) faciès de couche tufacé, (ii) faciès d'arénacé chaotique tufacé, (iii) faciès pyroclastique déposé dans l'eau, (iv) faciès d'arénacé d'une épaisseur moyenne à élevé, et (v) faciès de mince couche de roche argileuse. Ceux-ci sont des dépôts produit par des écoulements de gravité. Les conglomérats massifs de la Formation d 'Oak Bay ont été déposé par des coulés de débris contemporain au faille le long de la marge du bassin. Les strates dans l'homoclinal possèdent un clivage dominant $S_{1}$ avec une orientation oblique au lit de $35^{\circ}$ et un clivage $S_{2}$ développé localement. Les plis mineurs sont rares et les plis liés au $S_{1}$ sont absents.

La corrélation avec une séquence plus complète de Siluro-Dévonien dans un bloc faillé adjacent au Maine suggère que les formations d'Oak Bay et de Waweig soient fin Silurien (Ludlovian-Pridolian). Les centres volcaniques au Maine étaient des sources potentielles d'une grande partie du détritus épiclastique et pyroclastique dans la formation de Waweig. Les sections stratigraphiques distinctives dans les blocs faillés, fortement déformé, plus loin au sud-est certifient à l'architecture composée du bassin de Mascarene. L'évidence paléontologique existante peut indiquer que l'affaissement de ces blocs s'est produit progressivement plus tard au nord-ouest en raison de faille séquentiel.

La considération des rapports régionaux entre le bassin de Mascarene en rapport au Terrane de St-Croix et le Creux de Fredericton vers le nord-ouest et le Terrane de New River vers le sud-est suggère que le bassin a été développé par une 
dérive d'arrière-arc du silurien au dévonien précoce et a été flanquée au sud-est par un arc volcanique Ordovician tardif au Silurien (Kingston Arc).

[Traduit par la rédaction]

\section{INTRODUCTION}

Silurian to Early Devonian siliciclastic sedimentary and volcanic strata of the Mascarene Group of southwestern New Brunswick were deposited along the boundary between the Precambrian-Early Paleozoic peri-Gondwanan New River Terrane to the southeast and Ordovician St. Croix Terrane to the northwest (Fyffe and Fricker 1987; Johnson and McLeod 1996; Fig. 1). The sedimentary and volcanic sequences of the Mascarene Group are distributed in several fault-bounded blocks, each with a distinct stratigraphy (Brown and Helmstaedt 1970; Fyffe et al. 1992; Johnson and McLeod 1996), but their similar faunal assemblages (Boucot et al. 1966; Watkins and Boucot 1975) suggest that they were part of a composite marine basin. Vestiges of this basin, herein referred to as the Mascarene Basin (Fig. 1), extend from coastal Maine northeastward to the Long Reach area of New Brunswick. The existence of several volcanic centres, sporadic distribution of fossils, and major fault displacements make any paleogeographic and palinspastic reconstruction within this basin difficult.

New information reported herein on the stratigraphy, sedimentology and structure of the Oak Bay area in southwestern New Brunswick is used to reassess the paleogeographic relationships between the Mascarene Basin and its flanking terranes. The repercussions of this reevaluation on the Paleozoic accretionary history of this part of the Appalachian Orogen are discussed in the concluding section of the paper.

The northwestern margin of the Mascarene Basin in the Oak Bay area is marked by a Silurian conglomeratic sequence, lying with faulted unconformity on Early Ordovician black shale (Calais Formation of the Cookson Group) of the St. Croix Terrane (Fig. 2). A finer-grained Silurian siliciclastic sedimentary sequence overlies the conglomeratic sequence and is bounded to the south by Early Devonian plutonic rocks. MacKenzie (1940) referred to the conglomeratic sequence as the Oak Bay Formation and the overlying siliciclastic sequence as the Waweig Formation; MacKenzie and Alcock (1960a, 1960b) subsequently included both formations in the Mascarene Group. Ruitenberg $(1967,1968)$ gave a brief lithological description of these Silurian rocks in his structural study of the Oak Bay area.

Because only rudimentary information on the lithological character of the Oak Bay and Waweig formations is presently available in the existing literature, a detailed survey of the western and eastern shorelines of Oak Bay (Figs. 2, 3) was undertaken to supplement regional mapping by Fyffe (1991, 1997a, 1997b). Examination of the Oak Bay sections revealed that the Waweig Formation contains a larger component of volcanic and volcaniclastic rocks than previously recognized and permitted its subdivision into three members. This new information is used here to propose a correlation with volcanic-rich sections in adjacent fault blocks to the southeast in Maine and New Brunswick (Fig. 4).

\section{OAK BAY FORMATION}

The Oak Bay Formation comprises massive, generally clast-supported conglomerate typically containing 2 to $10 \mathrm{~cm}$ diameter pebbles and cobbles enclosed in a sandy matrix. The clasts are ellipsoidal to subspherical in shape and moderately to well rounded (Figs. 5a, 6a). A sample of 141 clasts collected from the western shore of Oak Bay revealed the following compositions: mafic volcanic rocks (39.0\%), feldspar porphyry $(35.5 \%)$, aphanitic felsic volcanic rocks $(16.3 \%)$, medium- to coarse-grained, equigranular granitoid rocks $(8.5 \%)$, and vein quartz $(0.7 \%)$. The Oak Bay Formation is at least $300 \mathrm{~m}$ thick on the western shore of the bay; a more accurate thickness could not be determined as its lower and upper contacts are unexposed (Fig. 3). Nevertheless, outcrop distribution along the powerlines east of the Waweig River suggests a minimum thickness of $600 \mathrm{~m}$ at the head of Oak Bay.

An unconformable relationship is locally preserved between graptolitic black shales of the Tremadocian Calais Formation and the Oak Bay Formation in a faulted section on Cookson Island in Oak Bay (Cumming 1966; Stringer and Burke 1985; Gates 1989). Slabs of cleaved black shale up to $25 \mathrm{~cm}$ in length, clearly derived from the underlying Calais Formation, together with abundant quartz-feldspar porphyry pebbles of unknown source, are found toward the base of the conglomerate (Figs. 5b, 6b, 6c) on the headwaters of Pout Brook $\sim 2.7 \mathrm{~km}$ along strike to the northeast of Oak Bay (Fyffe 1991). Farther to the northeast between Sawyer Brook and the Digdeguash River, the Oak Bay Formation is only $200 \mathrm{~m}$ thick and comprises thin-bedded, medium-grained, feldspathic sandstone layers (Fyffe 1997a; Fig. 6d) that on the Digdeguash River are interstratified with graded, pebbly turbiditic sandstone. The pebbly sandstone locally contains

Fig. 1. Geotectonic map of southwestern New Brunswick and adjacent Maine. Formations: New River Terrane: $P €=$ Precambrian basement and Cambrian volcanic rocks of Ellsworth Arc; St. Croix Terrane: Oc = Calais, Od = Digdeguash, Ok = Kendall Mountain, Ow = Woodland; Fredericton Trough: $\mathrm{Sf}=$ Flume Ridge; Kingston Arc: $\mathrm{Sbw}=$ Bayswater Group, $\mathrm{Sq}=$ Quoddy; Mascarene Basin: OSg = Goss Point, $\mathrm{Sbb}=$ Back Bay, Sd = Dennys, $\mathrm{Se}=$ Edmunds, $\mathrm{Sh}=$ Hersey, $\mathrm{SI}=$ Leighton, $\mathrm{Slt}=$ Letete, $\mathrm{Sob}=\mathrm{Oak} \mathrm{Bay}, \mathrm{Sw}=\mathrm{Waweig}, \mathrm{De}=$ Eastport; Post-Acadian strata: $\mathrm{Dp}=$ Perry, Dpk = Piskahegan Group; Ministers Island dyke: Jd = diabase. Faults: $(1)=$ Basswood Ridge, $(2)=$ Honeydale, (3) = Seavey, (4) = Sawyer Brook, (5) = Unnamed, $(6)=$ Falls Brook, $(7)=$ St. George, $(8)=$ Oak Bay, $(9)=$ Back Bay, $(10)=$ Beaver Harbour-Belleisle, $(11)=$ Lubec. Outlined area shows location of Figure 2. 


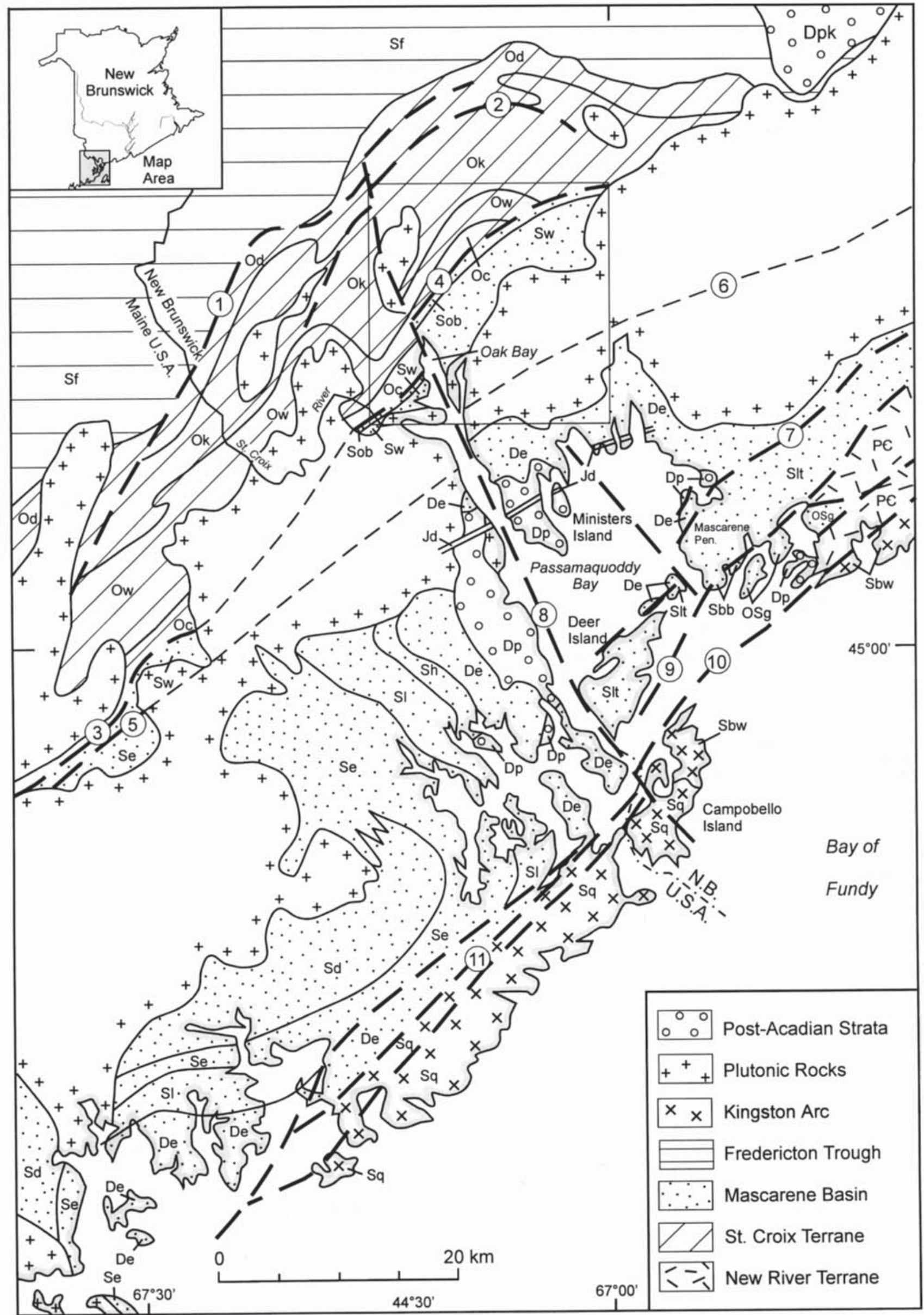




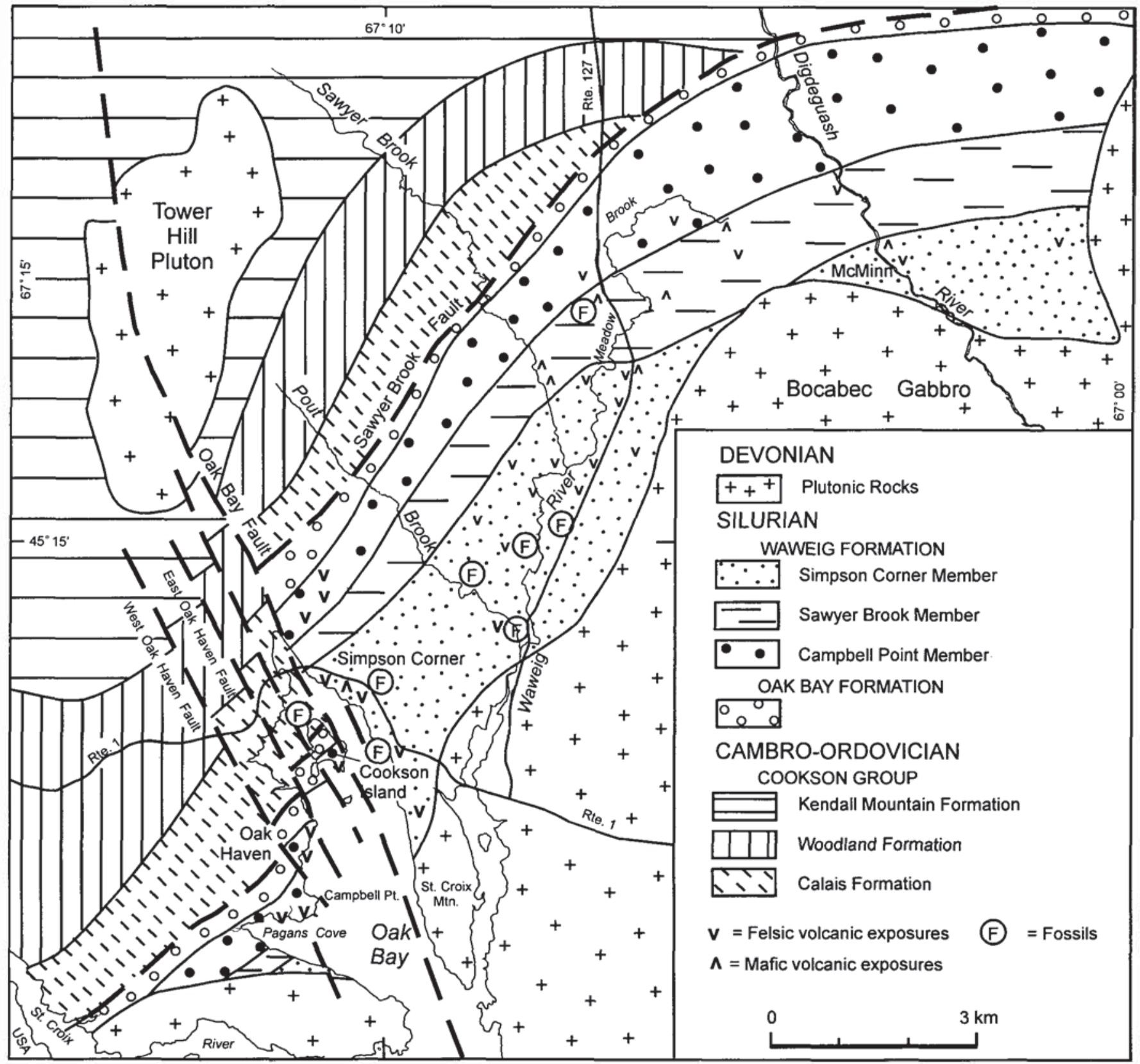

Fig. 2. Geological map of the Oak Bay area. Location is shown in Figure 1.

outsized cobbles of granite up to $8 \mathrm{~cm}$ in length and is displaced by small-scale synsedimentary faults (Fig. 5c).

The provenance and age of the igneous clasts in the Oak Bay Formation are unknown but their rounded shape suggests that they originally accumulated in a high-energy, shallow water, nearshore environment and were subsequently resedimented into deeper water (Ruitenberg 1967, 1968; Gates 1989). A single limestone clast in the conglomerate on
Cookson Island was also likely derived from a shelf environment (Cumming 1966). The presence of a sandy matrix in the internally structureless conglomerate of the Oak Bay Formation suggests deposition from cohesionless mass flows (Lowe 1982), presumably along a steep fault scarp (the Sawyer Brook Fault; no. 4 on Fig. 1). 


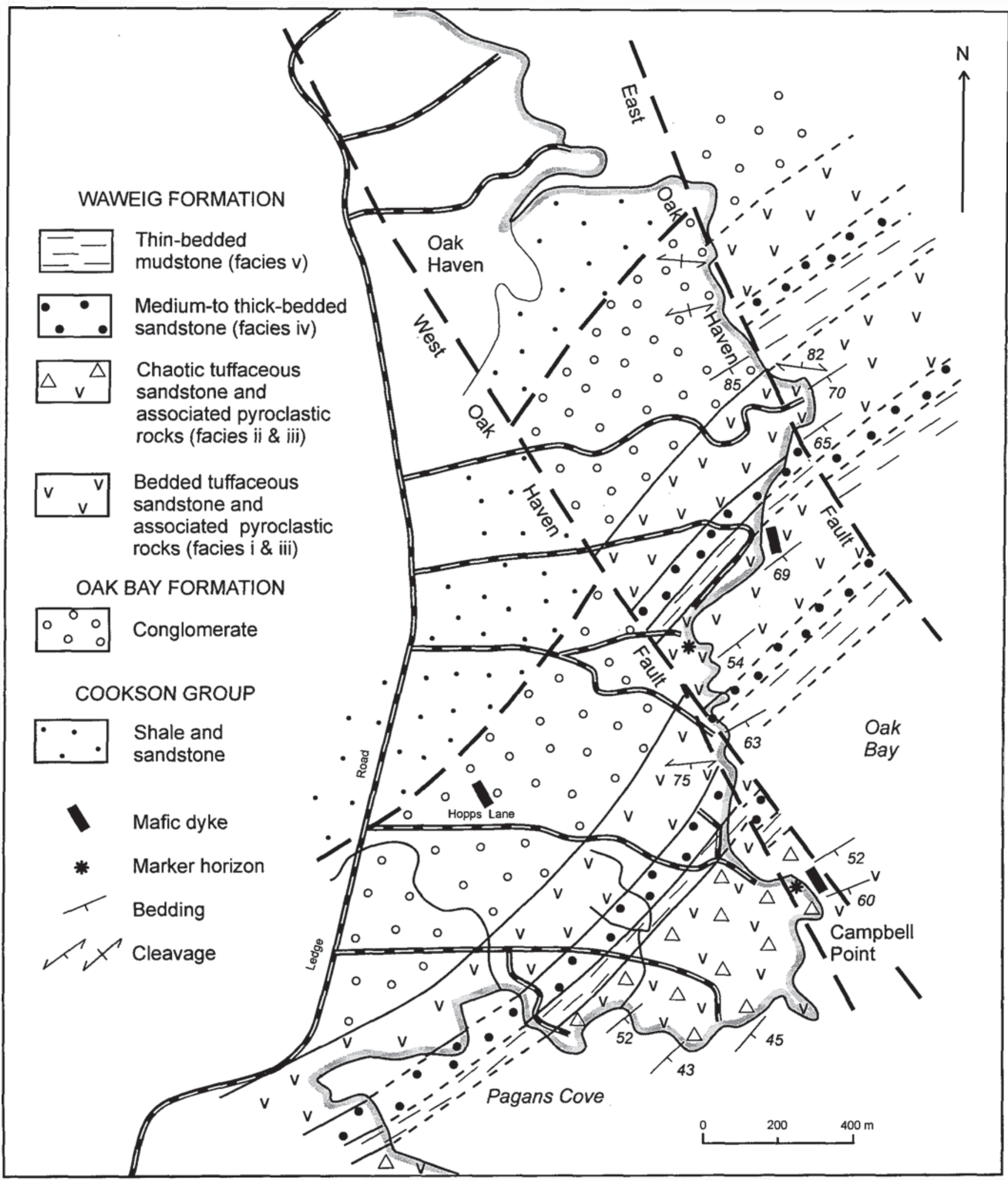

Fig. 3. Geological map of the western shore of Oak Bay between Oak Haven and Pagans Cove. 


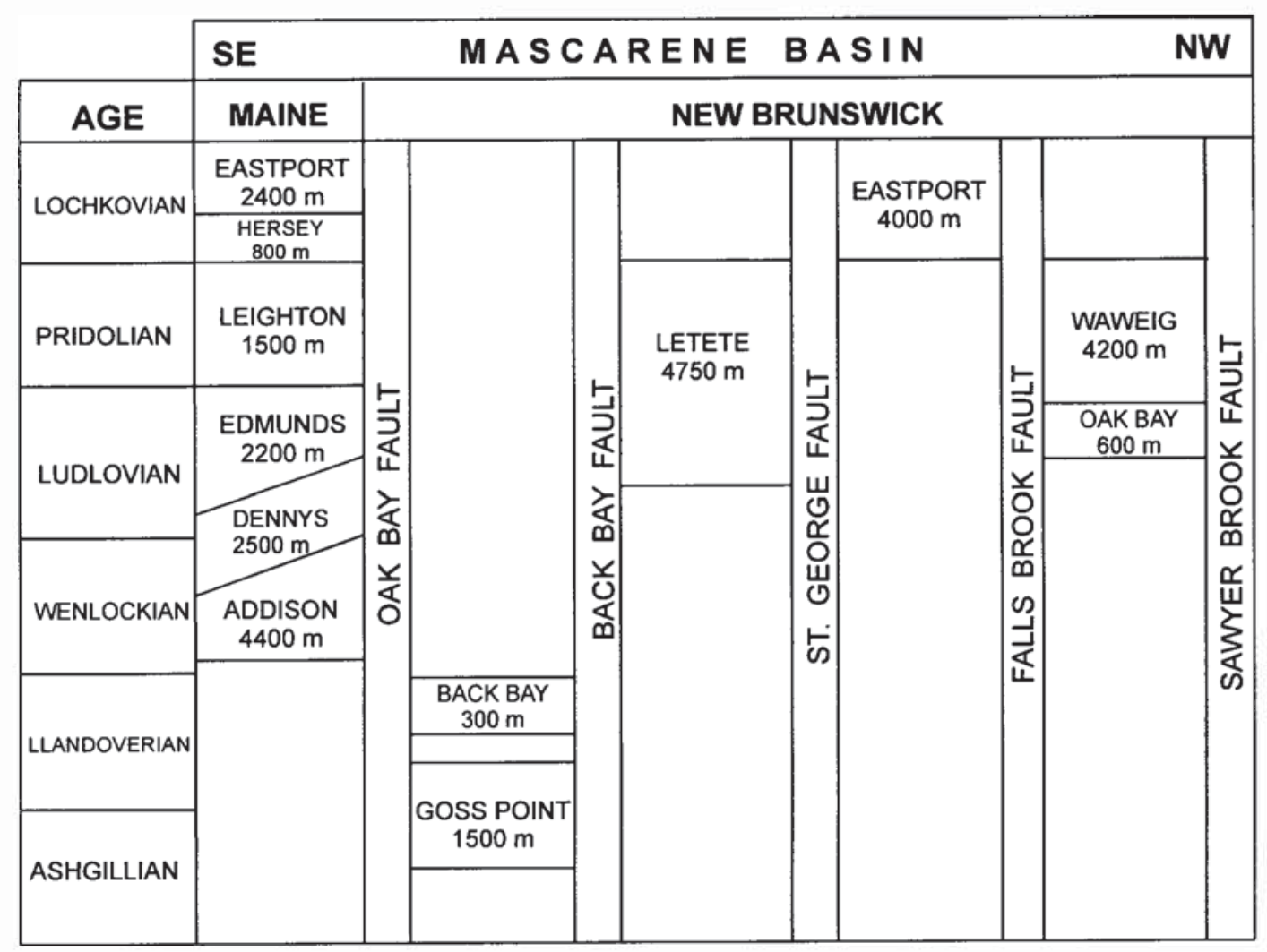

Fig. 4. Correlation chart showing stratigraphic ranges and estimated thicknesses for formations of the various fault blocks comprising the Mascarene Basin.

\section{WAWEIG FORMATION}

Regional mapping by Fyffe (1997a, 1997b) has demonstrated that the Waweig Formation can be divided into three members formally designated herein as: (i) Campbell Point, the lower member, named after Campbell Point on the western shore of Oak Bay; (ii) Sawyer Brook, the middle member, after Sawyer Brook located $7.5 \mathrm{~km}$ northeast of the head of Oak Bay; and (iii) Simpson Corner, the upper member, after Simpson Corner on Route 1, approximately 1.5 $\mathrm{km}$ southeast of the head of Oak Bay (Fig. 2). These sites best display the lithological character of the members and are designated as their stratotypes. A conformable contact between the Oak Bay and Waweig formations is exposed on Cookson Island (Gates 1989).

\section{Campbell Point Member}

The Campbell Point Member, a sequence of interstratified volcaniclastic and siliciclastic sedimentary and felsic volcanic rocks, is exposed along the western shore of Oak Bay from Oak Haven southward to Pagans Cove (Figs. 2,3). Bedding in this section strikes northeast, and the dips and younging directions are consistently to the southeast. Taking variations in dip and fault offsets into account, the member is estimated to have a true thickness of $-600 \mathrm{~m}$. Strata of the Campbell Point Member are locally divided into five lithofacies based essentially on lithological composition, bed thickness and internal bedforms: (i) bedded tuffaceous sandstone facies, (ii) chaotic tuffaceous sandstone facies, (iii) waterlain pyroclastic facies, (iv) medium- to thick-bedded sandstone facies, and (v) thin-bedded mudstone facies. Tuffaceous is used herein in the sense of Schmid (1981) to denote rocks that are a recognizable mixture of both pyroclastic and epiclastic fragments.

\section{(i) Bedded tuffaceous sandstone facies}

Units within this facies are best exposed on the unnamed point at Oak Haven (Fig. 3) and range from medium- to very thick-bedded. The very thick-bedded layers comprise poorly sorted, pebbly, greyish pink sandstone units typically up to 4 $\mathrm{m}$ thick that grade into $10-15 \mathrm{~cm}$ of moderately sorted, parallel-laminated, medium-grained sandstone, capped by 30 $40 \mathrm{~cm}$ of thickly laminated, fine-grained sandstone (Fig. 7a). Contacts with underlying beds are typically erosional. Pebbles are moderately to very angular felsic volcanic fragments less than a centimetre in diameter (Fig. 7b). Associated thinner $(10-25 \mathrm{~cm})$ beds generally lack the pebbly horizons and, instead, have coarse-grained feldspathic bases that commonly display load casts (Fig. 7c), and evidence of small-scale penecontemporaneous erosion including rip-up clasts of finegrained sandstone.

\section{(ii) Chaotic tuffaceous sandstone facies}

This facies is most extensively developed at Campbell Point and comprises slump-folded horizons and associated breccias. Slump folds, which occur interstratified with thinbedded sandstone, are isoclinal with wavelengths of about 30 $\mathrm{cm}$ and variable, generally steep, plunge (Fig. 8a). The 

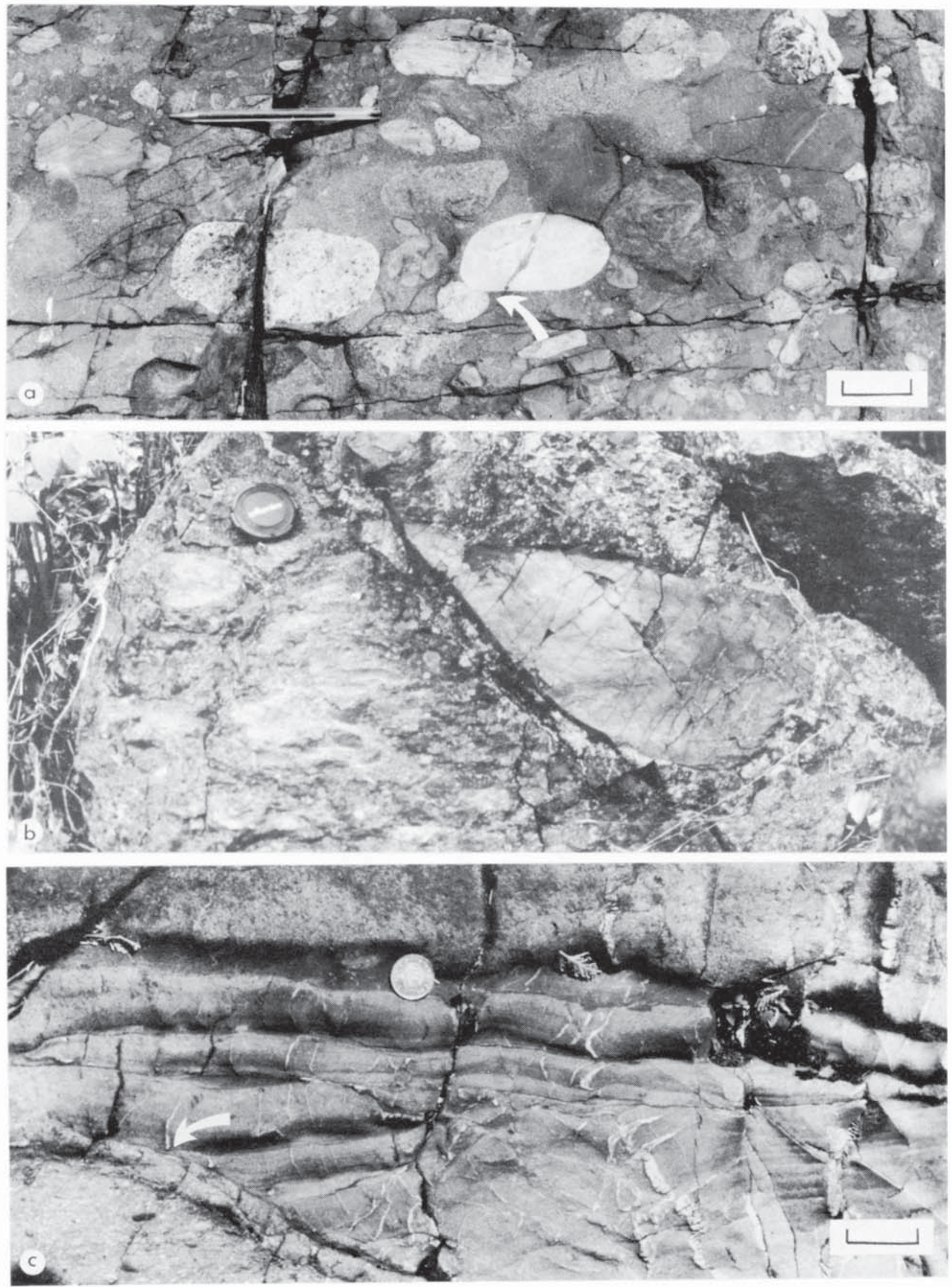

Fig. 5. Field photographs of the Oak Bay Formation: (a) laminated quartzite clast (upper centre) and felsic porphyry clast (lower left) in conglomerate, southwest corner of Cookson Island; arrow points to pressure solution indentation between clasts, bar scale $=5 \mathrm{~cm}$; (b) slab of black shale (centre right) in conglomerate near the headwaters of Pout Brook, lens cap $=5 \mathrm{~cm}$; (c) synsedimentary fault (arrow) between thinbedded feldspathic sandstone and pebbly sandstone on Digdeguash River, bar scale $=5 \mathrm{~cm}$. 

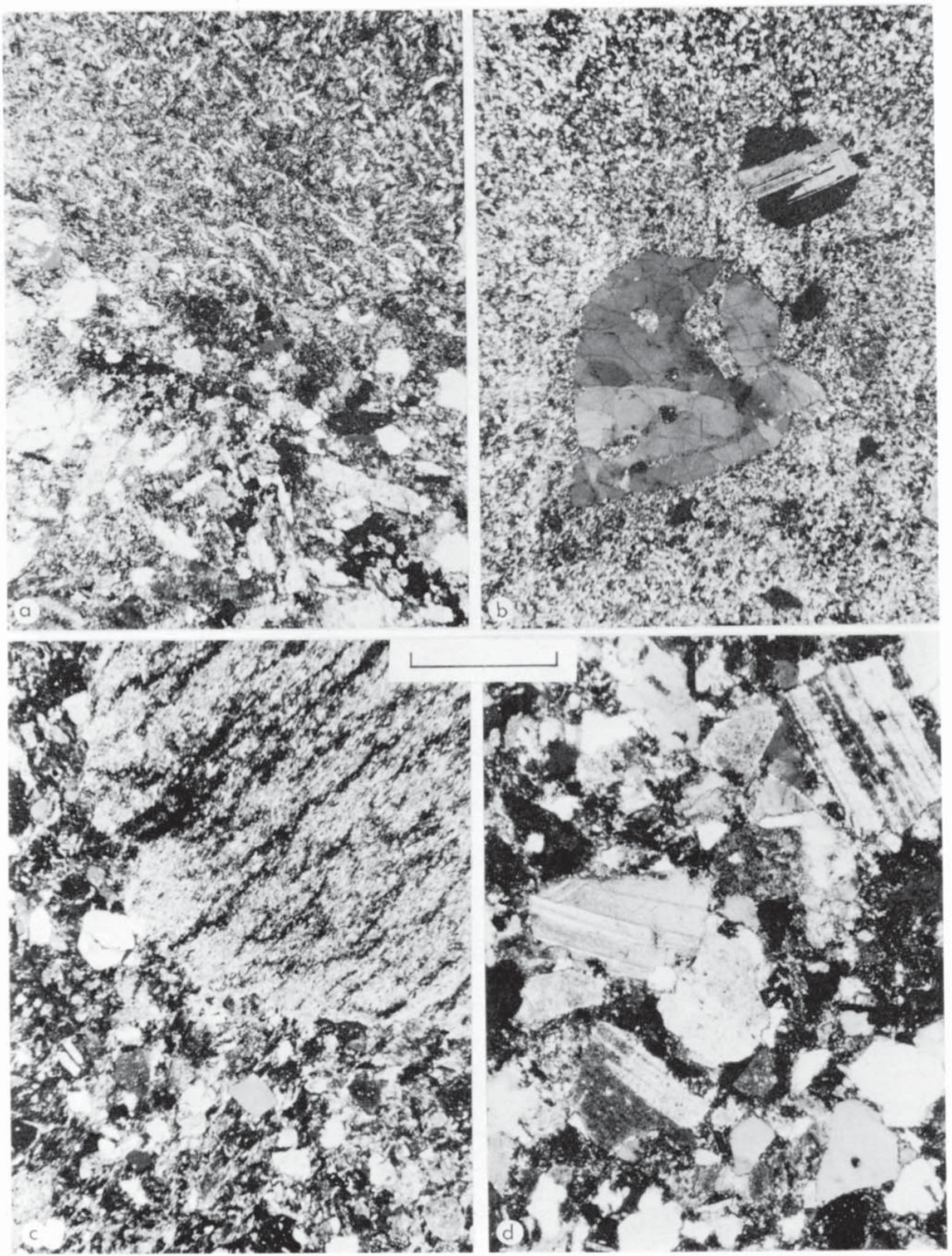

Fig. 6. Photomicrographs of the Oak Bay Formation (bar scale $=1 \mathrm{~mm}$ ): (a) mafic volcanic clast (upper half) enclosed in medium-grained feldspathic matrix (lower half) in conglomerate on western shore of Oak Bay; (b) quartz-feldspar porphyry clast from conglomerate on the headwaters of Pout Brook; (c) shale clast (upper right) from conglomerate on the headwaters of Pout Brook; (d) angular feldspar and quartz grains in coarse-grained feldspathic sandstone on powerline crossing Sawyer Brook. 

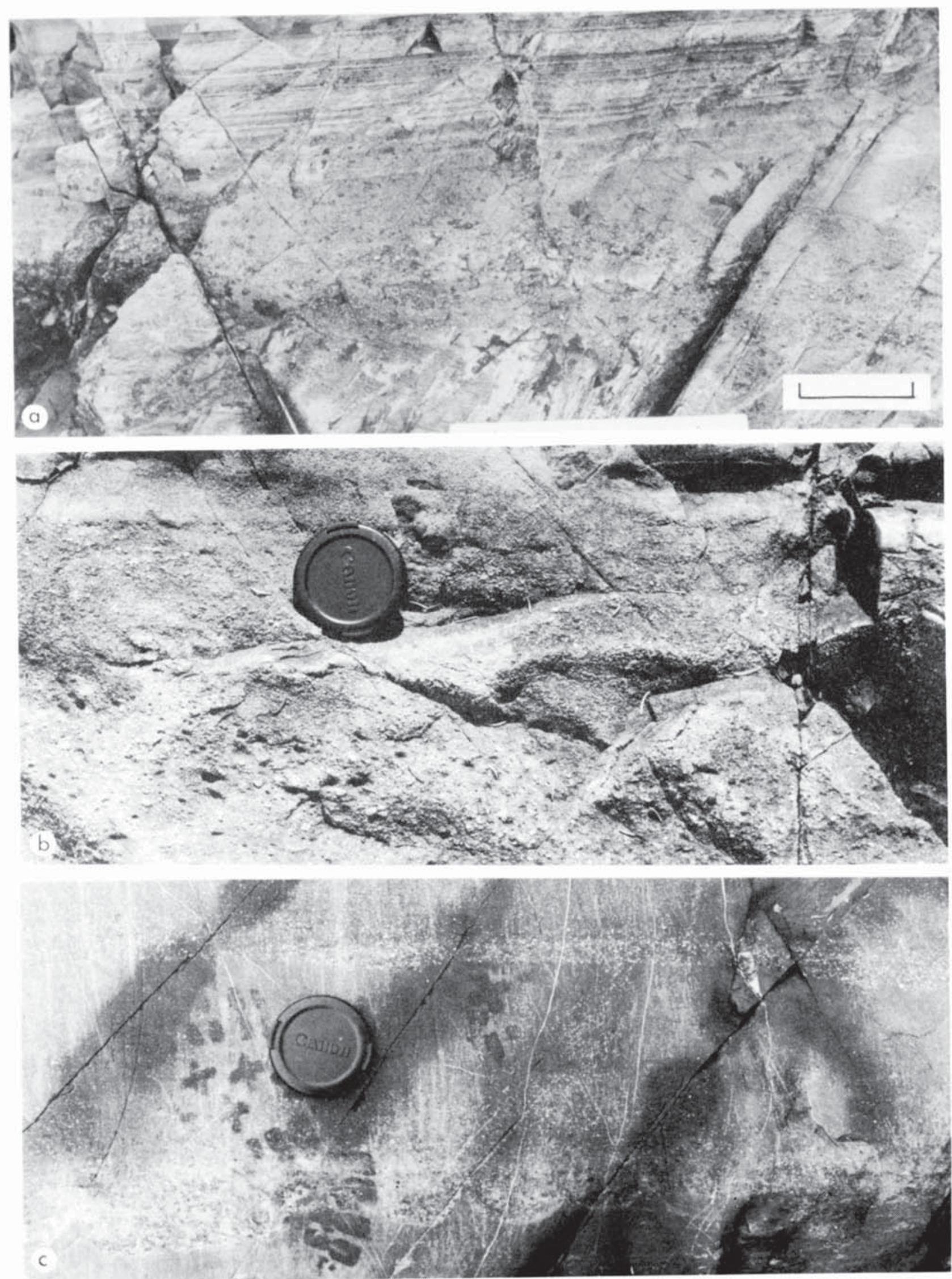

Fig. 7. Field photographs of bedded tuffaceous sandstone facies, Campbell Point Member of the Waweig Formation: (a) pebbly sandstone grading upward into laminated sandstone, bar scale $=5 \mathrm{~cm} ;(\mathrm{b})$ angular volcanic detritus in pebbly sandstone, lens cap $=5 \mathrm{~cm} ;(\mathrm{c})$ load casts at base of feldspathic bed, lens cap $=5 \mathrm{~cm}$. 

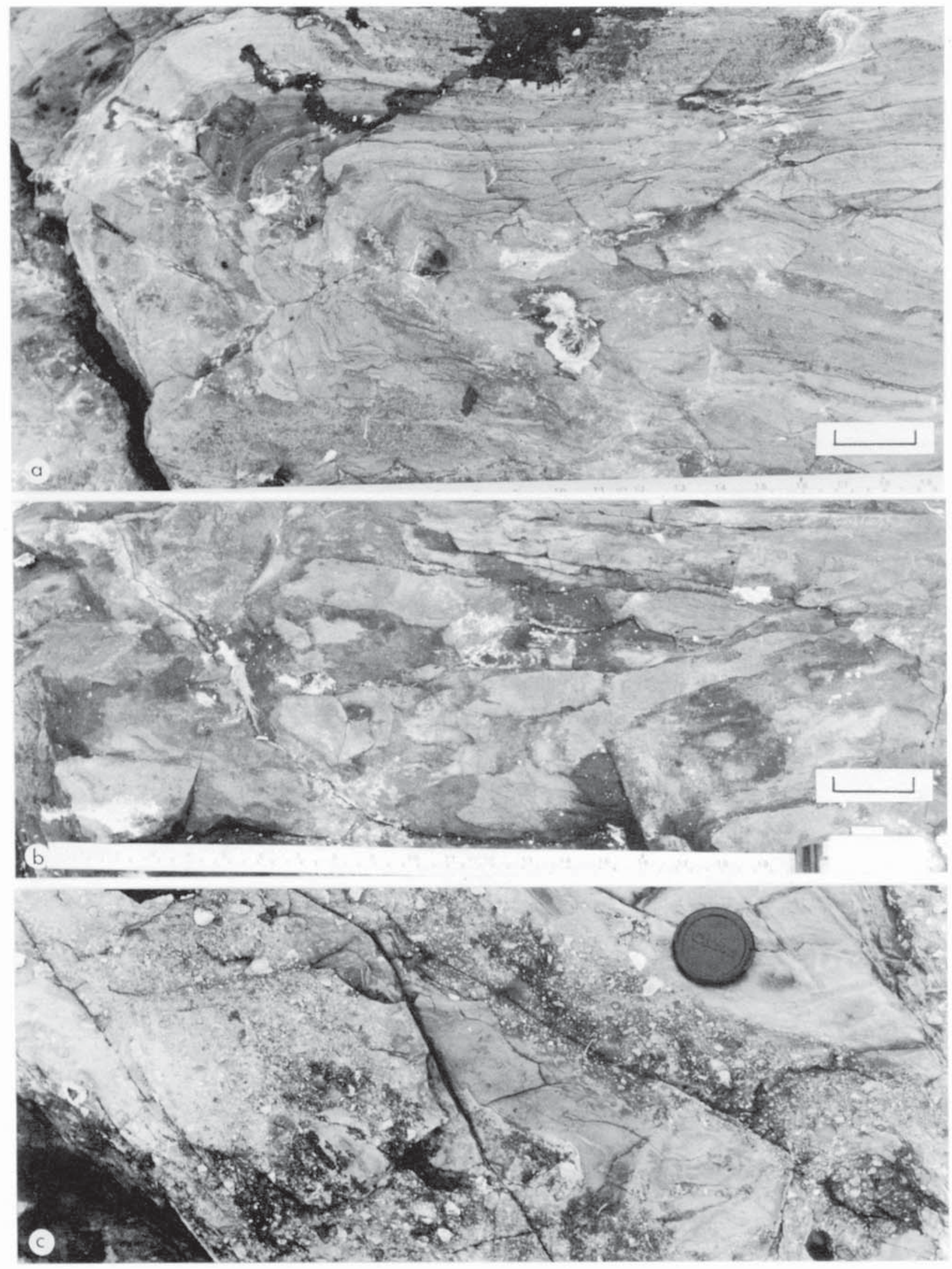

Fig. 8. Field photographs of chaotic tuffaceous sandstone facies, Campbell Point Member of the Waweig Formation: (a) slump fold in thinbedded sandstone, bar scale $=5 \mathrm{~cm}$; (b) disaggregated sandstone beds, bar scale $=5 \mathrm{~cm}$; (c) tuffaceous breccia containing felsic volcanic detritus and sedimentary blocks (under lens cap), lens cap $=5 \mathrm{~cm}$. 
sandstone layers are 2 to $5 \mathrm{~cm}$ thick and display turbiditic Bouma $T_{a b c}$ and $T_{b c}$ sequences (Bouma 1962) with erosive bases, and are commonly partly disaggregated (Fig. $8 \mathrm{~b}$ ). The associated breccias contain irregularly shaped, 1 to $10 \mathrm{~cm}$ long, plastically deformed fragments of medium grey, felsic crystal tuff set in an unstratified to poorly stratified, sandy to silty volcaniclastic matrix (Fig. 8c).

The chaotic facies is interpreted as a sequence of proximal debris flows and slump units that moved down the flanks of an active volcanic island (cf. Sigurdsson et al. 1980; Farquharson et al. 1984). These mass flows may have formed by remobilization of unconsolidated pyroclastic debris that incorporated semi-consolidated sediments from the volcaniclastic submarine apron situated farther downslope. This process would account for both the mixed pyroclasticsediment breccias and slump-folded sedimentary horizons. The previously described bedded tuffaceous sandstone (facies $i$ ), along strike to the northeast across the West and East Oak Haven faults (Fig. 3), is interpreted as more distal lateral facies equivalents deposited by high-density turbidity currents as the mass flows (facies ii) became diluted during transport (cf. Hampton 1972).

\section{(iii) Waterlain pyroclastic facies}

Both the bedded and chaotic tuffaceous facies are interstratified with massive units of medium grey, mediumgrained, commonly graded quartz-feldspar-crystal and crystallithic tuff up to $10 \mathrm{~m}$ in thickness that have locally incorporated fragments of fine-grained sandstone up to $15 \mathrm{~cm}$ in length near their base. These lapilli tuff units are commonly overlain by several metres of light grey, thin-bedded, finegrained, siliceous tuff with slightly coarser, laminated bases (Fig. 9a). The massive lapilli tuff units (Fig. 9b) are interpreted to have been deposited by high-density turbidity currents formed from contemporaneous pyroclastic flows entering the marine basin. The siliceous tuff beds are attributed to low-density turbidity currents related to episodes of less violent ash-rich eruptions generated during waning stages of volcanic activity (cf. Wright and Mutti 1981).

\section{(iv) Medium- to thick-bedded sandstone facies}

Beds 10 to $40 \mathrm{~cm}$ thick of fine-grained, greyish pink sandstone pass upward from massive to normally graded horizons into parallel-laminated, or parallel-laminated and cross-laminated, intervals (respectively, Bouma $T_{a b}$ and $T_{a b c}$ ). These sandy beds commonly have erosive bases and may be amalgamated (Fig. 10a) or separated by up to $2 \mathrm{~cm}$ of delicately parallel-laminated dark grey shale. Microscopic examination reveals that the quartz and feldspar grains are somewhat angular and were likely derived from first-cycle erosion of a volcanic source.

\section{(v) Thin-bedded mudstone facies}

Beds 2 to $8 \mathrm{~cm}$ thick (Fig. 10b) typically grade from a medium grey, cross- or parallel-laminated silty base into dark grey parallel-laminated to apparently structureless mudstone (Bouma $\mathrm{T}_{\text {cde }}$ and $\mathrm{T}_{\text {de }}$; Fig. 11a). Basal contacts are sharp and exhibit small-scale load casts; the deposit-feeding trace fossil Planolites Nicholson is present on some bedding surfaces (Fig. 11b). Rare, $4 \mathrm{~cm}$ thick, light grey, calcareous sandstone beds grade from a massive base through a parallel-laminated interval to a cross-laminated top (Bouma $\mathrm{T}_{\mathrm{abc}}$ ), indicating a current direction toward $290^{\circ}$. Calcareous nodules up to $15 \mathrm{~cm}$ long in the mudstone attest to slow sedimentation rates in the thin-bedded facies.

The medium- to thick-bedded sandstone facies and thinbedded mudstone facies are interpreted, respectively, as having been deposited from high- and low-density turbidity current flows (Lowe 1982; Pickering et al. 1986), generated by remobilization of the shallower part of the volcaniclastic submarine apron during periods of volcanic quiescence when coarse-grained pyroclastic material was not being provided by the emergent islands. This source would be expected to contain pyroclastic and first-cycle epiclastic grains but this distinction would be lost in the reworked sandy and finer fractions of resedimented gravity flows. Schmid (1981) recommended that all clastic grains be referred to as epiclasts if reworking was so extensive that it is impossible to determine a pyroclastic origin. This usage is followed here, and the thin-bedded mudstone and medium- to thick-bedded sandstone facies are referred to as epiclastic turbidites. Most of the unlaminated beds in the mudstone facies likely represent background hemipelagic sedimentation.

Lack of continuous exposure and the presence of faults makes it difficult to ascertain stratigraphic relationships, but at least two large-scale upward-fining cycles probably related to declining volcanic activity appear to be present in the Campbell Point Member. Thin-bedded epiclastic turbidites mark the top of the first cycle on the northern end of the unnamed point at Oak Haven where they underlie thickbedded tuffaceous and pyroclastic beds exposed on the point, and mark the top of the second cycle northwest of Campbell Point where they overlie similar tuffs (Fig. 3).

\section{Sawyer Brook Member}

The Sawyer Brook Member at its type locality on Sawyer Brook (Fig. 2) comprises a sequence of medium grey to black shale interstratified with several $10 \mathrm{~m}$ thick, dark greyish green mafic tuff horizons. The black shale contains cubes of pyrite up to $2 \mathrm{~mm}$ in size and small mafic volcanic clasts. The base and the top of the member is not exposed and only an estimate of $600 \mathrm{~m}$ can be given for its thickness on Sawyer Brook. Its thickness decreases southwestward to about $300 \mathrm{~m}$ on the eastern shore of Oak Bay where volcanic rocks are absent from the section (Fig. 2).

The lowest $50 \mathrm{~m}$ of strata included in the Sawyer Brook Member are exposed in a road cut on Route 127, 2 km to the northeast of the Sawyer Brook type section (Fig. 2). At the north end of the outcrop, dark green, $1 \mathrm{~m}$ thick, mafic hyaloclastite beds, containing 1 to $2 \mathrm{~mm}$ long mafic fragments (Fig. 12a) are interstratified with light green, $15 \mathrm{~cm}$ thick, fine-grained mafic ash beds. These mafic volcanic rocks are overlain by 10 to $15 \mathrm{~cm}$ thick, calcareous sandstone and noncalcareous mudstone beds at the south end of the road cut. Felsic crystal tuff in an outcrop $500 \mathrm{~m}$ to the north of the 

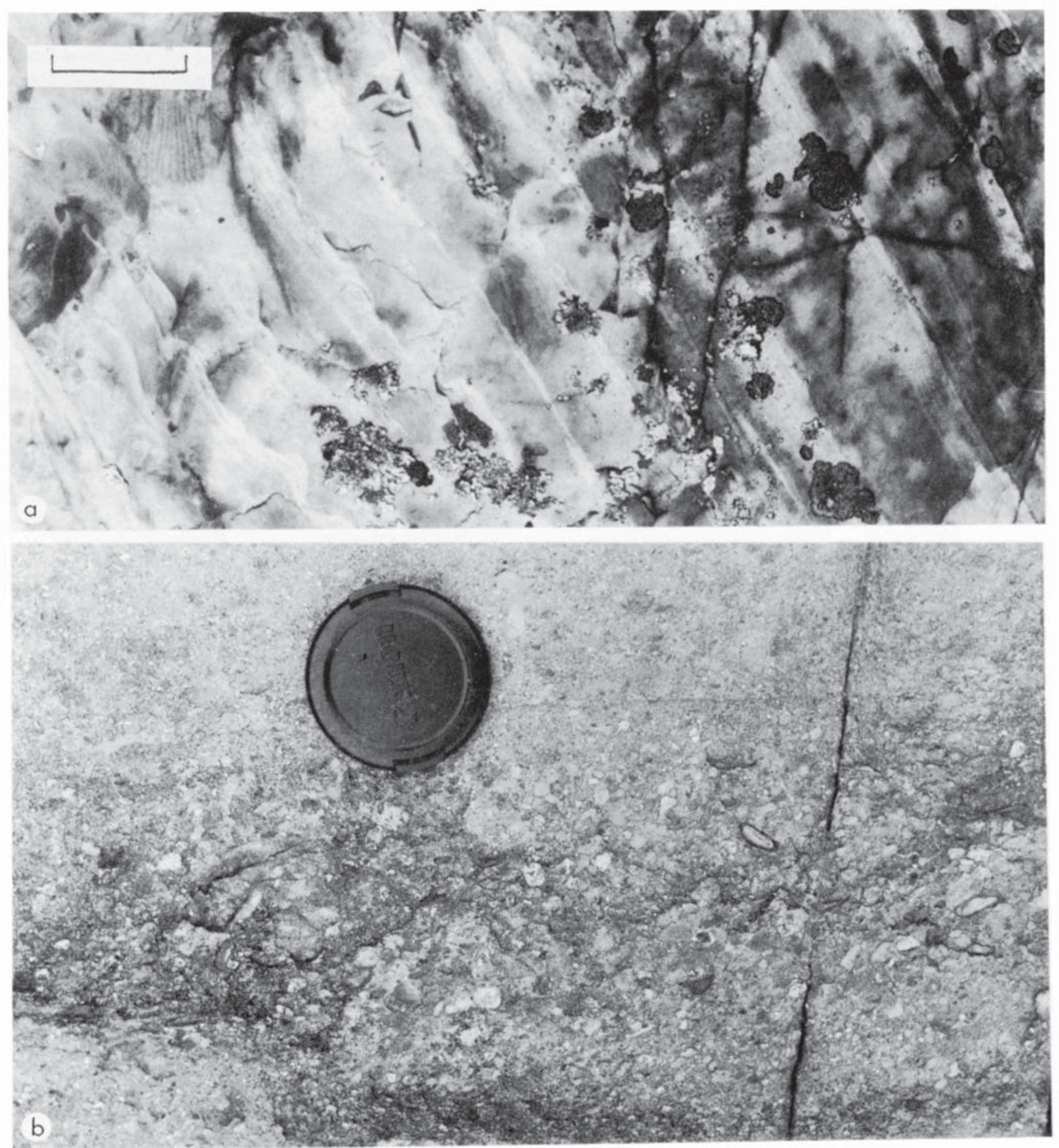

Fig. 9. Field photographs of waterlain pyroclastic facies, Campbell Point Member of the Waweig Formation: (a) thin-bedded siliceous tuff (tops to the left), bar scale $=5 \mathrm{~cm}$; (b) graded felsic crystal-lithic tuff, lens cap $=5 \mathrm{~cm}$.

Fig. 10. Field photographs of bedforms in sandstone facies and mudstone facies, Campbell Point Member of the Waweig Formation (lens cap $=$ $5 \mathrm{~cm}$ ): (a) amalgamated turbiditic sandstone layers of the medium- to thick-bedded sandstone facies, lens cap on plane of amalgamation; bed below lens cap exhibits a Bouma Tabc sequence; (b) thinly interbedded silty mudstones and mudstones of the thin-bedded mudstone facies, individual silty layers exhibiting Bouma $T_{\text {cde }}$ and $T_{d e}$ sequences. 


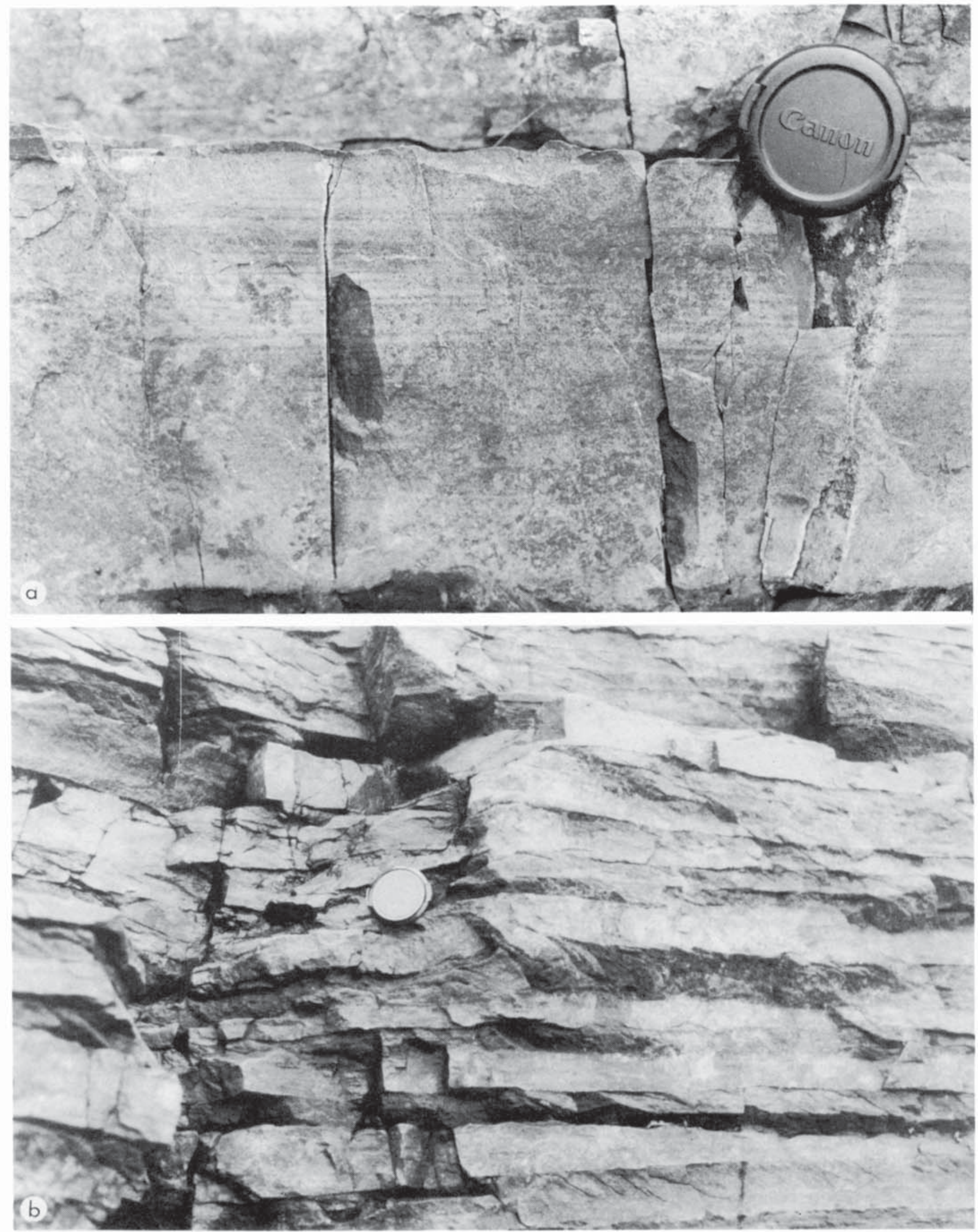



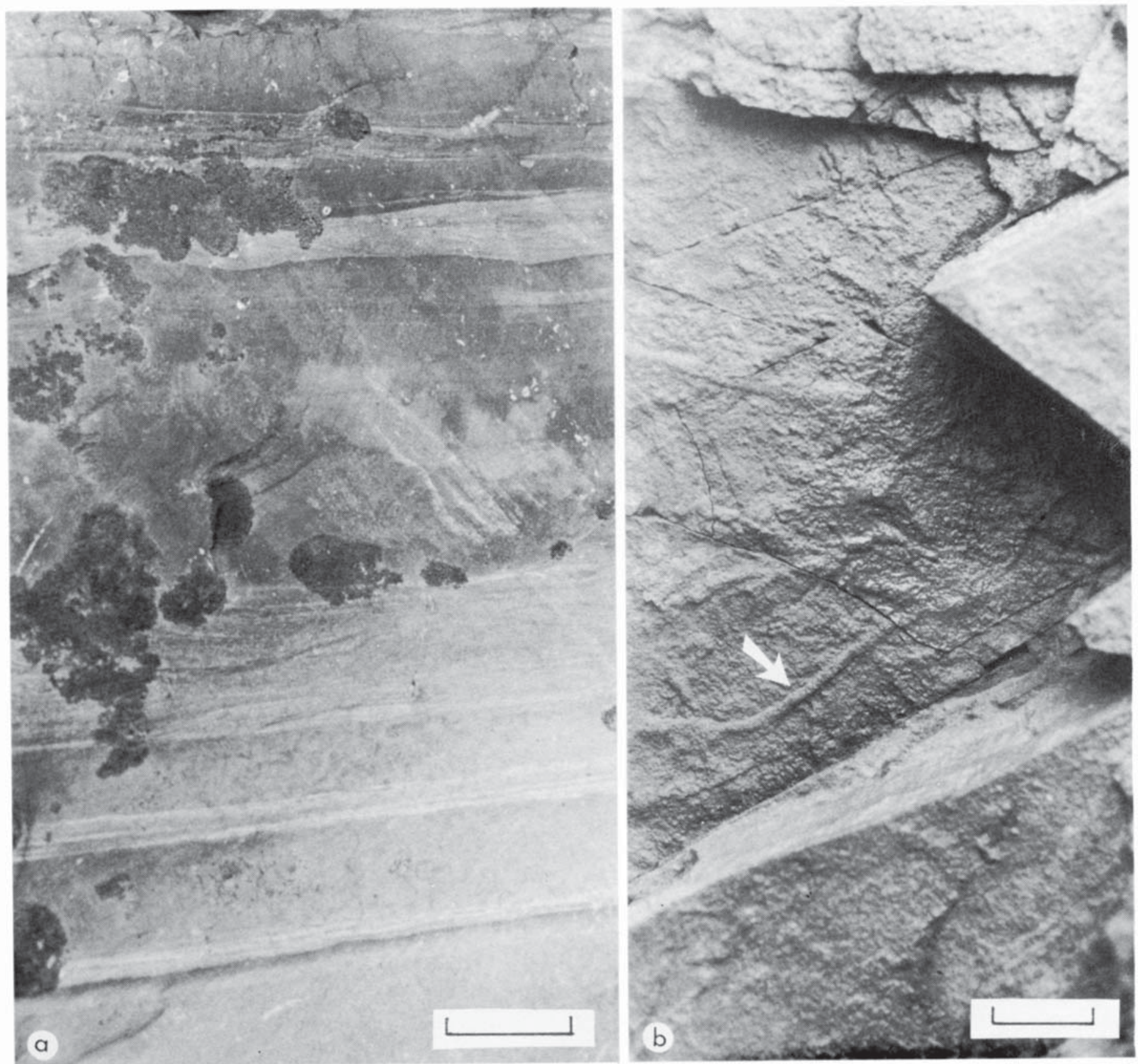

Fig. 11. Field photographs of thin-bedded mudstone facies, Campbell Point Member of the Waweig Formation (bar scale $=2 \mathrm{~cm}):(\mathrm{a}) \mathrm{cross}-\mathrm{and}$ parallel-laminated silty mudstones grading to structureless mudstones; (b) the trace fossil Planolites (arrow) preserved on the sole of a silty mudstone bed.

mafic volcanic exposure are the highest beds of the underlying Campbell Point Member exposed on Route 127.

The top of the Sawyer Brook Member can be defined on Route 127, $\sim 500 \mathrm{~m}$ south of Meadow Brook (Fig. 2), where interstratified, pyritic, 5 to $10 \mathrm{~cm}$ thick, medium grey, finegrained, feldspathic sandstone and dark grey shale beds are overlain by massive crystal tuffs of the Simpson Corner Member. A few thin beds of felsic crystal tuff are interstratified with shale of the Sawyer Brook Member in the vicinity of the Digdeguash River (Fig. 2).

It is concluded that the generally fine-grained clastic rocks of the Sawyer Brook Member were deposited by low- density turbidity currents and hemipelagic sedimentation during an extended period of diminished felsic volcanic activity. The localized nature of the mafic ash and hyaloclastite beds suggests that they may have been extruded from proximal vents on the seafloor.

\section{Simpson Corner Member}

The Simpson Corner Member is exposed more or less continuously along the eastern shore of Oak Bay from Route 1 south to St. Croix Mountain where its upper part is truncated by the Bocabec Gabbro (Fig. 2); its minimum thickness is 


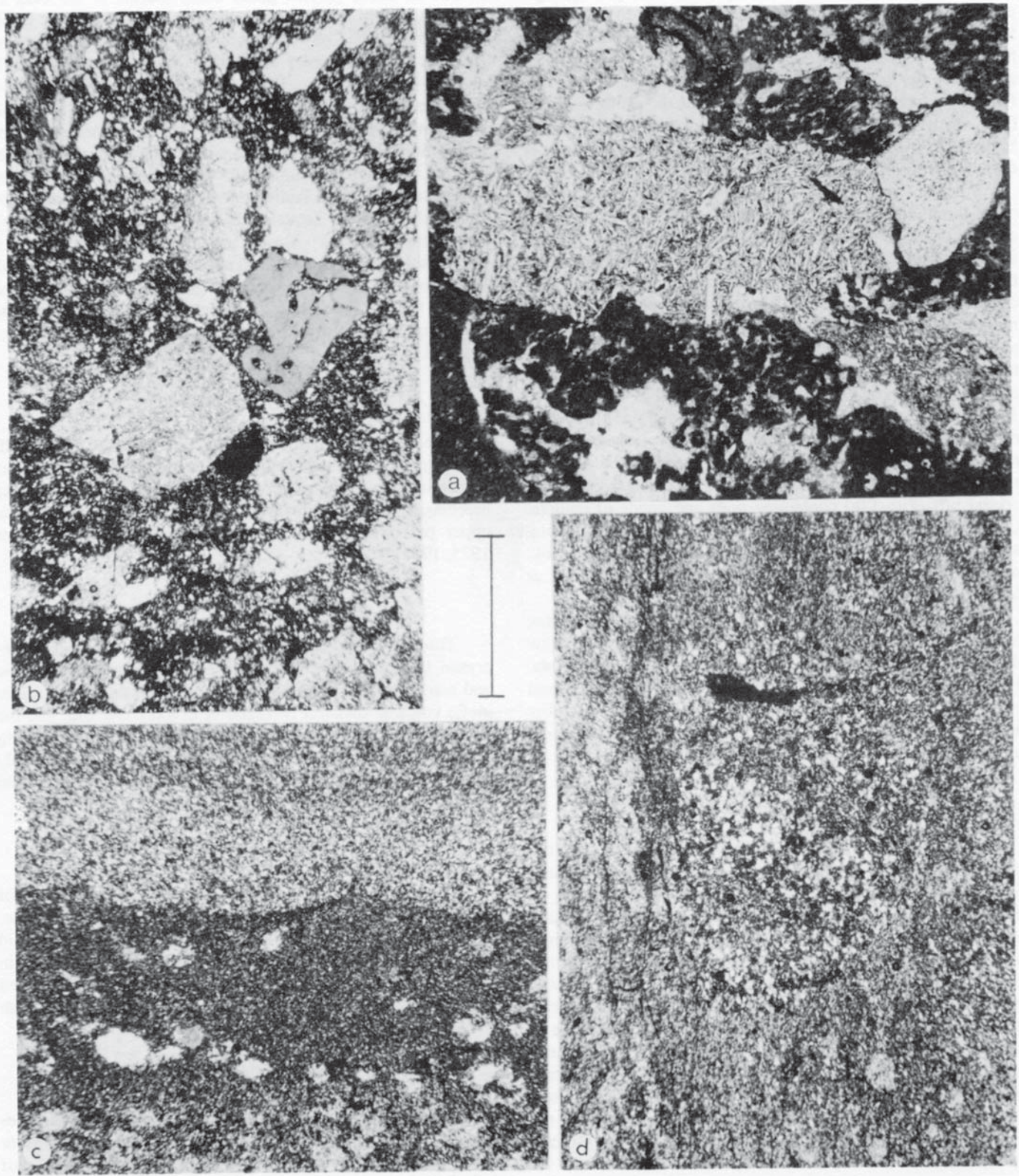

Fig. 12. Photomicrographs of the Sawyer Brook and Simpson Corner members of the Waweig Formation (bar scale = $1 \mathrm{~mm})$ : (a) mafic hyaloclastite in Sawyer Brook Member on Route 127; (b) felsic crystal tuff in upper part of Simpson Corner Member, eastern shore of Oak Bay; (c) flame structures at the base of sandstone bed and spots of incipient cordierite in underlying mudstone, lower part of Simpson Corner Member, eastern shore of Oak Bay; (d) burrow (coarser-grained area) in bioturbated sandstone, middle part of Simpson Corner Member, eastern shore of Oak Bay. 
$\sim 3000 \mathrm{~m}$. Siliciclastic sedimentary rocks comprising light pinkish grey, fine-grained sandstone grading to dark grey, laminated silty mudstone (Bouma $\mathrm{T}_{\mathrm{abd}}$ ) are dominant in the Simpson Corner Member. Beds are typically 10 to $35 \mathrm{~cm}$ thick and rarely up to a metre in thickness. Small-scale load and flame structures are present at the base of the sandstone beds (Fig. 12c), and the mudstone beds are commonly weakly bioturbated (Fig. 12d). Sandstone beds are absent in the upper $600 \mathrm{~m}$ of section.

Volcanic rocks are interstratified with the sedimentary rocks throughout much of the section along the eastern shore of Oak Bay. These volcanic rocks are briefly described as follows, measured from a stratigraphic level near the base of the Simpson Corner Member, the starting point being the first outcrop just south of the Oak Bay causeway on Route 1: at 80 m upsection, $4 \mathrm{~m}$ of felsic crystal-lithic tuff with 2 to $3 \mathrm{~mm}$ plagioclase phenocrysts; at $400 \mathrm{~m}, 12 \mathrm{~m}$ of felsic lithic-crystal tuff with 1 to $2 \mathrm{~cm}$ volcanic fragments; at $500 \mathrm{~m}, 5 \mathrm{~m}$ of amygdaloidal mafic volcanic rock; from 1100 to $1200 \mathrm{~m}, 3$ to $15 \mathrm{~cm}$ thick beds of normally graded, fine-grained feldsparrich tuff containing scattered brachiopod-rich lenses; at 1400 $\mathrm{m}$, highly fractured felsic volcanic rock transected by a NNWtrending shear zone; and at $2465 \mathrm{~m}, 12 \mathrm{~m}$ of graded, felsic crystal tuff (Fig. 12b) containing pods and bands of epidote. Good exposures of these volcanic rocks are also found along strike to the northeast on Route 127 south of Meadow Brook, on Meadow Brook itself, and on the Digdeguash River at McMinn (Fyffe 1997a; Fig. 2).

The depositional environment of the Simpson Corner Member is difficult to interpret unequivocally as few diagnostic indicators have been observed in the strata. However, the presence of partial Bouma sequences and continuity with the underlying Sawyer Brook Member suggests deposition in relatively deep water conditions, though additional work is required to test this hypothesis.

\section{Coastal Maine Sequence}

Correlation of the Oak Bay-Waweig stratigraphy with the better documented volcanic-rich sequence of coastal Maine, $30 \mathrm{~km}$ to the south-southwest, is hampered by the paucity of diagnostic fossils in both regions. Thus, various authors have expressed differing opinions on whether the depositional range of the Oak Bay and Waweig formations spanned most of the Silurian (Cumming 1966; Ruitenberg 1967, 1968) or was restricted to the latest Silurian (Pickerill 1976). A brief description of the Coastal Maine sequence is presented here in an attempt to resolve these alternative views. One informal and five formal formations have been recognized in Maine, named in ascending stratigraphic order: (i) Addison (informal), (ii) Dennys, (iii) Edmunds, (iv) Leighton, (v) Hersey, and (vi) Eastport (Bastin and Williams 1914; Gilman 1966; Gates 1969, 1975, 1977, 1989).

\section{Addison Beds}

The lowest part of the Silurian-Early Devonian volcanic sequence, exposed near Addison on the Maine coast ( 10 km to the west of the area shown in Fig. 1), has not been given formal status and will be referred to here as the Addison beds.
A $900 \mathrm{~m}$ thick, greyish green conglomerate at the base of these beds is in probable fault contact with feldspathic schist and amphibolite of the Cambrian Ellsworth Formation (Gilman 1966). Angular to rounded clasts of granite, mafic and felsic volcanic rocks, and quartzite in the conglomerate are commonly 3 to $10 \mathrm{~cm}$ and locally up to $25 \mathrm{~cm}$ in size. This conglomerate is overlain to the east by fine-grained sandstone and minor felsic volcanic rocks with a minimum thickness of $3500 \mathrm{~m}$ (calculated assuming a conglomerate horizon exposed farther to the east is a faulted repetition of the basal unit to the west; otherwise the sequence is nearly twice that thickness). Interstratified black shale and felsic volcanic rocks, presumably part of the Addison succession in an adjacent fault block to the north, are dated by graptolites as Wenlockian (Gates 1989). The contact between the Addison beds and overlying mafic volcanic rocks of the Dennys Formation is not exposed.

\section{Dennys Formation}

The Dennys Formation is composed of mafic flows, tuff, and agglomerate interstratified with subordinate tuffaceous sandstone, mudstone and conglomerate, and felsic flows and breccias. It is $\sim 2500 \mathrm{~m}$ in thickness and interdigitates in its upper part with the overlying Edmunds Formation (Gates $1975,1977)$.

\section{Edmunds Formation}

The Edmunds Formation comprises felsic breccia, lithiccrystal tuff and flows interstratified with maroon mudstone and conglomerate, dark grey tuffaceous mudstone, and minor mafic volcanic rocks. It is $\sim 2200 \mathrm{~m}$ in thickness and, like the Dennys Formation, contains an abundant but long-ranging brachiopod fauna indicative of deposition in a relatively shallow marine environment (Gates 1975, 1977; Watkins and Boucot 1975).

\section{Leighton Formation}

The Leighton Formation comprises $\sim 1500 \mathrm{~m}$ of interstratified grey, slightly calcareous, fine-grained sandstone, mudstone and shale with minor felsic and mafic flows and tuffs (Gates 1975, 1977). These shallow marine beds contain abundant brachiopods, mostly Salopina submedia, associated with ostracodes diagnostic of the latest Silurian (Berdan 1971).

\section{Hersey Formation}

The Hersey Formation contains $\sim 800 \mathrm{~m}$ of maroon, finegrained, cross-bedded sandstone and mudstone with minor grey shale and pink knobbly limestone. Its upper part interdigitates with volcanic rocks of the overlying Eastport Formation (Gates 1975, 1977).

\section{Eastport Formation}

The Eastport Formation was first established along the shore of Passamaquoddy Bay in coastal Maine by Bastin and 
Williams (1914). The term was applied to similar rocks in New Brunswick by Pickerill and Pajari (1976). The Eastport Formation comprises amygdaloidal mafic flows, agglomerate and peperitic breccia; massive to flow-banded felsic flows, welded and non-welded lapilli tuff, pisolitic tuff, and peperitic breccia; and grey to maroon, ripple-marked, fine-grained sandstone locally displaying mud cracks and rain pits, and conglomeratic lenses (Hay 1967; Gates 1969, 1975, 1977; Pickerill and Pajari 1976; Pickerill et al. 1978; Van Wagoner et al. 1988, 1994). Three cycles of mafic to felsic volcanism totalling $\sim 2400 \mathrm{~m}$ have been recognized in Maine (Amos 1963) and four cycles totalling $4000 \mathrm{~m}$ in New Brunswick (Van Wagoner et al. 1994). Sedimentary depositional environments range from intertidal in the lower part of the section to fluvial in the upper part (Pickerill and Pajari 1976; Pickerill et al. 1978; Van Wagoner et al. 1988). Ostracodes from both the Hersey and the Eastport formations are indicative of an Early Devonian age (Berdan 1971).

\section{Correlation of the OAK BAy-WaWeig AND Coastal MaIne SEQUences}

Available paleontological evidence allows only a broad correlation to be made between the Oak Bay-Waweig and Coastal Maine sequences. A pentameroid brachiopod in the limestone clast from conglomerate on Cookson Island in Oak Bay indicates that the Oak Bay Formation is no older than late Llandovery, although it may be significantly younger (Cumming 1966). It is, however, not likely to be any younger than Ludlovian based on the stratigraphic thickness of the overlying Waweig Formation. The conglomerate at the base of the Addison beds appears to underlie Wenlockian shale and therefore is probably somewhat older than the Oak Bay Formation (Fig. 4).

The Waweig Formation contains fossils at various stratigraphic horizons (Fig. 2). Cumming (1966) reported the presence of Salopina sp. on the eastern shore of Oak Bay, $\sim 1600 \mathrm{~m}$ stratigraphically above the base of the Simpson Corner Member. Pickerill (1976) made an extensive collection of a Salopina submedia-dominated assemblage on Route 1 south of Simpson Corner, $\sim 400 \mathrm{~m}$ stratigraphically below the coastal locality. Other Salopina-bearing sites are found $4 \mathrm{~km}$ along strike to the northeast on the Waweig River and Route 127 (Fyffe 1997a, 1997b; Fig. 2). The lowest known occurrence of Salopina is located in mafic tuffs on Route 127 near the base of the Sawyer Brook Member.

Salopina-bearing grey shale in the Leighton Formation of coastal Maine contains ostracodes indicative of a Pridolian (latest Silurian) age (Berdan 1971) so that the fossiliferous Simpson Corner and Sawyer Brook members are also likely to be Pridolian. However, given the short duration of the Pridolian (Tucker and McKerrow 1995; Tucker et al. 1998), the underlying Campbell Point Member may extend down into the Ludlovian, even with the high sedimentation rates expected in volcanically active submarine basins (Lonsdale 1975).

The above arguments suggest that the Oak Bay and Waweig formations were probably deposited between the Ludlovian and Pridolian, essentially the depositional range spanned by the Edmunds and Leighton formations (Fig. 4). Thus the source of much of the volcanic and volcaniclastic rocks of the Waweig Formation could reasonably be located in coastal Maine where shallow-water to subaerial, Silurian felsic volcanic domes and debris flows have been described from the Edmunds Formation (Gates 1975, 1977). General thickening of the sediment gravity flows to the southwest in the Campbell Point Member is consistent with such a derivation.

\section{STRUCTURE OF THE OAK BAY HOMOCLINE}

A persistent southeastward dip of bedding in the Oak Bay and Waweig formations, particularly well exposed in the Campbell Point and Simpson Corner members across the strike at Oak Bay, continues northeastward along strike for 20 km (Fyffe 1991, 1997a, 1997b), forming a major homocline (Cumming 1966), herein termed the Oak Bay homocline. Bedding dips $\sim 60^{\circ} \mathrm{SE}$ in the lower part of the $4.5 \mathrm{~km}$-thick section and $\sim 40^{\circ} \mathrm{SE}$ in the upper part, and strikes $050-070^{\circ}$. The homocline is truncated along its western, southern and eastern margins by undeformed plutonic rocks of Early Devonian age (Amos 1963; McLeod 1990; Abbott 1991; Fig. 1).

A narrow NE-striking belt of polydeformed sedimentary and minor volcanic rocks in Maine, $35 \mathrm{~km}$ to the southwest of Oak Bay (Fig. 1), has been correlated with the Waweig Formation of New Brunswick (Westerman 1978, 1981). This belt widens farther to the southwest near Wesley (beyond the area shown in Fig. 1), where possible correlatives of both the Oak Bay and Waweig formations dip $\sim 45^{\circ} \mathrm{SE}$ (Westerman 1981; Gates 1989) and therefore likely represent the continuation of the Oak Bay homocline into Maine.

Unnamed felsic pyroclastic rocks occur to the southeast of the Oak Bay homocline in the Wesley area. A faunal assemblage of bivalves, corals and gastropods in associated gently northwesterly dipping redbeds suggests a Late Silurian age and a shallow marine depositional environment for these pyroclastic rocks (Westerman 1978, 1981; Gates 1989). They are, therefore, included in the Edmunds Formation and considered to be part of the Coastal Maine sequence (Fig. 1).

\section{Bounding faults}

Along its northern margin in New Brunswick, the Oak Bay Formation regionally truncates various formations of the Cookson Group at an apparent regional unconformity that is largely replaced by the Sawyer Brook Fault (Fyffe et al. 1992; Fig. 1). The faulted boundary is not exposed but is inferred by the presence of highly stretched pebbles in conglomerate exposed on the west side of the St. Croix River (Amos 1963; Fig. 1) and by quartz veining proximal to the contact on the Digdeguash River. The Seavey Fault (Gates 1982; no. 3 on Fig. 1), which separates the Oak Bay homocline in the Wesley area of Maine from the Cookson Group to the northwest, is interpreted herein to be the continuation of the Sawyer Brook Fault in New Brunswick because both faults separate the St. Croix Terrane from the Mascarene Basin (cf. Fyffe et al. 1992; Fig. 1).

Gates (1982) introduced an unnamed fault (no. 5 on Fig. 1) between the oppositely dipping sequences correlated with 
the Waweig and Edmunds formations in the Wesley area of Maine. This fault thus marks the contact between the Oak Bay homocline and Coastal Maine sequence and is considered to be the southwestern extension of the Falls Brook Fault (no. 6 on Fig. 1), which is buried beneath plutonic rocks in the Oak Bay area of New Brunswick. An abrupt change in the regional gravity field recorded across the Falls Brook Fault has been interpreted as the faulted boundary between dense Precambrian rocks of the New River Terrane and Paleozoic sedimentary rocks of the St. Croix Terrane (Thomas and Willis 1989; McLeod 1990).

It should be noted that exposed Precambrian basement in the New River Terrane to the southeast of the Falls Brook Fault in New Brunswick is overlain in part by Cambrian volcanic rocks (Johnson and McLeod 1996). In the Penobscot Bay area of Maine to the southwest of the area shown in Figure 1, the Turtle Head Fault defines the boundary between Cambrian volcanic rocks of the Ellsworth Formation and Ordovician sedimentary rocks of the Penobscot Formation in the adjacent St. Croix Terrane (Stewart et al. 1995). It is accepted herein that the Falls Brook Fault represents the northeastern continuation of the Turtle Head Fault and thus defines the northwestern boundary of the New River Terrane hidden beneath the Mascarene Basin in New Brunswick (Fyffe and Fricker 1987). Westerman (1979) originally proposed that the Seavey Fault and Turtle Head Fault were equivalent; the difference between his interpretation and that presented here is, to a certain extent, only one of detail as the Seavey-Sawyer Brook Fault and Falls Brook Fault can both be considered splays of the Turtle Head Fault (Fig. 1).

\section{Cleavage and folds}

A steep cleavage $\left(\mathrm{S}_{1}\right)$ in the Waweig Formation dips between $75^{\circ} \mathrm{S}$ and $75^{\circ} \mathrm{N}$, more steeply than bedding in the Oak Bay area, and strikes close to $075^{\circ}$, commonly clockwise of bedding (Stringer and Pajari 1982; Stringer and Burke 1985; Fig. 3). The cleavage, developed mainly in mudstone and shale, is locally obscured at Oak Bay by intense fracturing associated with NNW-trending faults. The average orientations of bedding $\left(060^{\circ} / 55^{\circ} \mathrm{SE}\right)$ and cleavage $\left(073^{\circ} / 88^{\circ}\right.$ $\mathrm{SE}$ ) indicate that the $\mathrm{S}_{1}$ cleavage is $\sim 35^{\circ}$ oblique to bedding. The cleavage is defined by a weak to moderate alignment of fine-grained phyllosilicate minerals and elongate quartz grains. A shallow, southerly dipping cleavage $\left(\mathrm{S}_{2}\right)$ is locally developed in the Oak Bay Formation on the Digdeguash River near the faulted contact with the polydeformed Cookson Group.

Sporadic growth of fine-grained biotite laths and of elongate retrograde cordierite spots parallel to the $S_{1}$ cleavage has been attributed to post-tectonic recrystallization within the metamorphic aureole of the Early Devonian Bocabec Gabbro (Stringer and Pajari 1982). Euhedral garnet porphyroblasts are found in the Simpson Corner Member near the contact with the gabbro on the inlet to the Waweig River.

Alignment of pebbles in the Oak Bay Formation on Cookson Island and on the western shore of Oak Bay, in a plane striking $065-090^{\circ}$ and dipping between $70^{\circ} \mathrm{S}$ and $80^{\circ} \mathrm{N}$, subparallel to sparse $S_{1}$ cleavage in the matrix, is apparently tectonic in origin; mutual pressure solution indentations between pebbles indicate flattening perpendicular to the alignment plane (Fig. 5a). The intensity of deformation appears to increase toward the southwest where bedding and schistosity in the Oak Bay conglomerate on the Maine side of the St. Croix River dip $\sim 60^{\circ} \mathrm{SE}$, and pebbles and cobbles display moderate to extreme stretching in a subhorizontal linear arrangement (Amos 1963). Variably plunging, polyphase minor folds in rocks correlated with the Oak Bay and Waweig formations near Wesley, Maine (Westerman 1978, 1981), associated with intense stretching of conglomerate pebbles, may be related to high strain localized along the Seavey Fault (Gates 1982, 1989).

Minor folds are rare in the Oak Bay and Waweig formations, and folds related to the $S_{1}$ cleavage appear to be absent. The presence of isoclinal folding associated with widespread polyphase deformation, equivalent to that in the Cookson Group as proposed by Ruitenberg $(1967,1968)$ and Brown (1972), is not substantiated in the Oak Bay homocline. Moreover, the minor structures appear to be equivalent to those in the Eastport Formation to the south of the Bocabec Gabbro, where a single, steep ENE-trending cleavage is present (Hay 1967; Stringer 1982) and associated minor folds are rare.

\section{Oak Bay fault system}

The Oak Bay homocline is offset by the major NNWtrending Oak Bay Fault (no. 8 on Fig. 1) and by several parallel subsidiary faults (MacKenzie 1940; Cumming 1966; Gates 1989). Two of the more prominent subsidiary faults, exposed on the western side of Oak Bay, are herein named the East and West Oak Haven faults (Figs. 2, 3). Other subsidiary faults are present: (i) along the eastern shore of Oak Bay (Stringer and Burke 1985), where NNW-trending diabasic dykes are locally brecciated in the fault zone; (ii) on the south side of Pagans Cove, where the contact of the Bocabec Gabbro is displaced; and (iii) along the western side of Cookson Island, where the Oak Bay Formation appears to be significantly offset (Gates 1989; Fig. 2).

Persistent sinistral subhorizontal strike-slip displacement on the Oak Bay fault system is indicated by: (i) $s$-asymmetry and subvertical plunge of tight minor drag folds that deform both bedding and $S_{1}$ cleavage in the Waweig Formation on the west side of the Oak Bay Fault on Cookson Island; (ii) steeply SSE-plunging, open drag folds in the Waweig Formation in which the ENE-strike of bedding curves anticlockwise over several metres to a NNW-strike against the East and West Oak Haven faults; (iii) a distinctive volcanic marker horizon (Fig. 7c) with a measured sinistral offset of $\sim 700 \mathrm{~m}$ across the trace of the West Oak Haven Fault (Fig. 3); and (iv) slickensides plunging $130^{\circ} / 35^{\circ}$ on the vertical, calcite-filled East Oak Haven fault plane.

The sinistral displacement of the Oak Bay Formation on the Oak Bay Fault is $\sim 2.4 \mathrm{~km}$, and the aggregate displacement including the subsidiary faults between Pagans Cove and the head of Oak Bay is $\sim 4 \mathrm{~km}$ (Cumming 1966; Fig. 2). Farther north, sinistral displacement of the Tower Hill pluton by the Oak Bay Fault diminishes to $\sim 1 \mathrm{~km}$ (Fig. 2). South of Oak Bay, where the Oak Bay fault system apparently converges to a single fault plane (Cumming 1966; Hay 1967), the sinistral 
offset of the contact between the Early Devonian Eastport Formation and Early Devonian plutonic rocks is $\sim 5 \mathrm{~km}$ (Fig. 1); similar to the aggregate offset at Oak Bay. Still farther south in Passamaquoddy Bay, the base of the Late Devonian Perry Formation is sinistrally offset $\sim 1 \mathrm{~km}$ on another subsidiary NNW-trending fault (Stringer et al. 1991).

\section{Age constraints}

The development of the Oak Bay homocline and $S_{1}$ cleavage predated intrusion of the Early Devonian plutons. Movement on the Falls Brook and Sawyers Brook faults, and on the Turtle Head and Seavey faults, their proposed extensions into Maine, also predated emplacement of these plutons. Faulting was, therefore, contemporaneous, at least in part, with Silurian to Early Devonian volcanic activity, during which time significant displacement may have been taking place between the depositional site of the volcanic and volcaniclastic beds of the Waweig Formation, and their probable volcanic source area in coastal Maine (Fig. 1).

Movement on the main Oak Bay Fault predated intrusion of the Early Jurassic Ministers Island dyke (Fig. 1), although the dyke appears to be displaced $\sim 2.5 \mathrm{~km}$ by another NNWtrending fault to the east of Ministers Island in Passamaquoddy Bay (Burke and Stringer 1993). Pre- and postLate Devonian sinistral strike-slip movements have been postulated on the Oak Bay fault system on the basis of the lesser offset of the Perry Formation on a subsidiary fault (Stringer and Burke 1985; Stringer et al. 1991). The Oak Bay and other NNW-trending faults have also been interpreted as transfer faults, approximately coeval with the Early Jurassic dykes, associated with the opening of the Atlantic Ocean (Williams and Hy 1990; Williams et al. 1995). A Mesozoic age for the through-going NNW-trending faults would appear more likely if, as suggested by Webb (1969), significant strike-slip movement occurred on major NE-trending faults such as the Beaver Harbour-Belleisle Fault (no. 10 on Fig. 1) as late as the Carboniferous.

\section{SOUTHEASTERN BOUNDARY OF THE MASCARENE BASIN}

Whereas a basal conglomerate defines the northwestern margin of the Mascarene Basin, its southeastern boundary is marked by a series of narrow fault blocks of Precambrian basement commonly separated by slices of Paleozoic strata. The St. George Fault (no. 7 on Fig. 1), which separates gently dipping beds of the Eastport Formation along the northern shore of Passamaquoddy Bay from polydeformed sandstone and shale, and felsic and mafic lithic tuff and flows of the Letete Formation on the Mascarene Peninsula, defines the northwestern margin of this highly disrupted zone in New Brunswick. The presence of Salopina sp. suggests a Pridolian age for at least the southeastern part of the Letete Formation (Ruitenberg 1968; Donohoe 1973, 1978; Johnson and McLeod 1996).

The largest tectonic sliver in the basement block southeast of the Back Bay Fault (no. 9 on Fig. 1) is underlain by the Goss Point Formation. Limestone associated with quartzose sandstone in the lower part of the Goss Point sequence is dated as Late Ordovician (late Caradocian to Ashgillian) by a conodont assemblage that possesses elements of both the Atlantic and Mid-continent faunal regions; felsic tuff and agglomerate, locally containing clasts of limestone, and minor mafic flows constitute the upper part of the sequence (Donohoe 1973, 1978; Johnson and McLeod 1996; Nowlan et al. 1997). A small sliver in this block contains Silurian shallow-water sandstone and felsic tuff of the Back Bay Formation of probable late Llandoverian age on the basis of Pentamerus sp. (Boucot et al. 1966; Donohoe 1973, 1978).

The block to the southeast of the Lubec Fault (no. 11 on Fig. 1) in coastal Maine is underlain by pyritic black shale and laminated mudstone, pillow lava and breccia intercalated with limestone, and minor felsic flows and tuff of the Quoddy Formation (Gates 1961, 1969, 1977). A late Llandoverian age is indicated by graptolites in the shale, and the brachiopod Stricklandia lens ultima in limestone fragments enclosed in the mafic breccia (Gates 1961; Boucot et al. 1966). The Quoddy Formation is intruded by abundant mafic dykes referred to by Gates (1961) as the Cutler Diabase. The Quoddy Formation extends northeastward onto Campobello Island in New Brunswick (Fig. 1), where it contains an abundance of thick-bedded, turbiditic sandstone in a section that is at least $1500 \mathrm{~m}$ thick (McLeod and Rast 1988). Its contact with the underlying Bayswater Group (see below) is conformable (M. McLeod, personal communication 1998).

Felsic lithic tuff and minor associated shale to the southeast of the Beaver Harbour-Belleisle Fault along the Bay of Fundy coast and on Campobello Island (Fig. 1) are herein included in the Bayswater Group, a stratigraphic unit recently established on the Kingston Peninsula $\sim 50 \mathrm{~km}$ inland along strike to the northeast (Barr et al. 1997). The lithic tuffs are mylonitized and intruded by a steeply dipping swarm of weakly to strongly foliated mafic and minor felsic dykes. The tuffs were assumed to be Precambrian and, in part, Late Silurian in age whereas the associated dykes were considered to be Precambrian (Rast 1979; Rast and Dickson 1982; Nance 1987; Currie 1988; McLeod and Rast 1988). However, subsequent U-Pb dating of zircon from quartz-feldspar porphyry and comagmatic volcanic rocks in the type area of the Bayswater Group yielded Early Silurian ages (Doig et al. 1990; Barr et al. 1997). ${ }^{40} \mathrm{Ar} /{ }^{39} \mathrm{Ar}$ dating of hornblende suggests that some of the mafic dykes could be as young as Late Silurian or Early Devonian (Nance and Dallmeyer 1993).

\section{MASCARENE BASIN - FREDERICTON TROUGH RELATIONSHIP}

The paleogeographic relationship between the Mascarene Basin, apparently, in part, floored by Precambrian basement (Currie 1988; Thomas and Willis 1989) and the Silurian Fredericton Trough (McKerrow and Ziegler 1971), lying on opposite flanks of the Ordovician St. Croix Terrane (Fig. 1), has been a matter of conjecture since the first detailed geological survey of southwestern New Brunswick was carried out by Bailey and Matthew (1872). MacKenzie and Alcock (1960a, 1960b) considered the Oak Bay and Waweig formations on the northwestern margin of the Mascarene 
Basin to be entirely younger than strata of the St. Croix Terrane and Fredericton Trough. They noted that the generally dark grey shale and generally quartz-rich sandstone (Calais, Woodland, and Kendall Mountain formations of Ludman 1987, 1991) of the St. Croix Terrane graded conformably upward to the north through dark grey lithic sandstone (Digdeguash Formation of Ruitenberg 1967, 1968) into light grey, calcareous sandstone and shale (Flume Ridge Formation of Ruitenberg 1972) of the Fredericton Trough.

Ruitenberg (1967, 1968) and Ruitenberg and Ludman (1978) suggested that the Oak Bay and Waweig formations on the southeastern flank of the St. Croix Terrane were lateral facies equivalents of the Digdeguash Formation on the northwestern flank and, consequently, assigned a Late Silurian to Early Devonian age to the latter. However, Fyffe and Miller (1992) argued that the Digdeguash Formation is more likely to be Late Ordovician, because underlying quartzite and shale of the Kendall Mountain Formation are dated as early Caradocian by graptolites, and calcareous strata correlated with the overlying Flume Ridge Formation contain a Silurian (Llandoverian-Wenlockian) fauna along strike in Maine (Osberg 1968). ${ }^{40} \mathrm{Ar} /{ }^{39} \mathrm{Ar}$ dating of a gabbro intruding the Digdeguash and Flume Ridge formations has established that both are certainly no younger than late Wenlockian-early Ludlovian (West et al. 1992). As documented herein, conglomerate of the Oak Bay Formation and volcanic and volcaniclastic beds of the Waweig Formation bear little resemblance in terms of lithology or structural style to the polydeformed, epiclastic sedimentary rocks of the Digdeguash and Flume Ridge formations and are considered to be considerably younger (Ludlovian-Pridolian vs. late Caradocian-Wenlockian).

\section{DISCUSSION AND CONCLUSIONS}

Interpreting the tectonic history of the southeastern margin of the Appalachian Orogen is extremely difficult because strike-slip faulting has juxtaposed several tectonostratigrapic terranes that may have originated in widely separated parts of evolving oceanic basins (Barr and White 1996; van Staal et al. 1998). In such a geologically complex area it is not possible to arrive at a unique reconstruction of the paleogeography particularly due to the lack of demonstrable overlapping cover sequences. We present an admittedly speculative plate tectonic model based on the integration of new information reported herein with pertinent data from the published literature. Obviously, any model that purports to explain the accretionary history of southwestern New Brunswick needs to assess the paleogeographic relationships between the St. Croix Terrane, the Fredericton Trough and the Mascarene Basin.

The southeastern boundary of the Fredericton Trough has been interpreted as a cryptic suture marking a plate margin that evolved from a convergent arc setting in the midPaleozoic to a major strike-slip displacement zone in the Late Paleozoic (see Bradley 1983 and references therein for a review). However, these early plate tectonic models generally lacked documented evidence for arc magmatism, let alone for the age and polarity of subduction. Southerly subduction in the Silurian and Devonian beneath the New River Terrane has generally been invoked to account for the presence of the Coastal Maine volcanic sequence (see also Ludman et al. 1993), but such models are difficult to reconcile with the distribution of Paleozoic arc and back-arc volcanic rocks that are now known to exist in the New River Terrane. The latter, as used here to include, on its southeastern margin, the Brookville Terrane of Barr and White (1996) has a Cambrian tectonothermal history similar to that of the New River Terrane (Nance and Dallmeyer 1994).

Recent geochemical and geochronological data indicate that Paleozoic suprasubduction zone volcanism was occurring in the New River Terrane much earlier than previously proposed i.e., in both the Early Cambrian Mosquito Lake Road Formation and Late Cambrian Annidale Group (McLeod et al. 1992; McLeod et al. 1994; Johnson and McLeod 1996) with an intervening period of within-plate volcanism in the Middle Cambrian Buchmans Creek Formation (Greenough et al. 1985), using the new time-scale of Landing et al. (1998). Van Staal et al. (1996) considered the Cambrian arc rocks now situated on the New River Terrane to be highly allochthonous. They proposed that an arc, generated above a subduction zone dipping away from the northwestern margin of the Miramichi Terrane, was subsequently obducted over the St. Croix Terrane (according to van Staal and Fyffe (1995), the Miramichi and St. Croix terranes, located on opposite margins of the Fredericton Trough, are both part of the Gander Terrane as defined by Williams and Hatcher (1982) in Newfoundland).

Although the contact of the Mosquito Lake Road Formation against Precambrian basement is faulted and that of the Annidale Group is not exposed, basalt of the Buchmans Creek Formation lies nonconformably on Precambrian granite (Currie 1988); furthermore, conglomerate interbedded with the basalt contains pebbles of the underlying granite. This evidence leaves no doubt that volcanism was taking place in the New River Terrane during the Cambrian. We, therefore, consider the possibility that a number of marginal basins opened along the southeastern margin of the Iapetus Ocean so that several separate peri-Gondwanan terranes may have existed in the Early Paleozoic (including the New River Terrane of Johnson and McLeod 1996), and the Brookville and Caledonia terranes of Barr and White 1996) rather than just a single Avalon Terrane (Williams and Hatcher 1982). Closure of these basins at distinct intervals would then account for the presence of volcanic rocks with arc affinities in both the Cambrian and Silurian of southwestern New Brunswick.

We propose that the Mosquito Lake Road and Annidale volcanic rocks in New Brunswick and the Ellsworth volcanic rocks in Maine were part of a Cambrian arc / back-arc complex (referred to here as the Ellsworth Arc) that developed on the Precambrian New River Terrane. Subduction is interpreted to have been to the southeast, based on the fact that the Annidale arc volcanic rocks located farther to the northwest are younger (Late Cambrian) than those of the Mosquito Lake Road (Early Cambrian). The latter would then represent a remnant of the Ellsworth Arc left behind as the arc rifted apart in the Middle Cambrian (Fig. 13a). Volcanism presumably ceased in this arc by the Early Ordovician when the New River Terrane became accreted to the Miramichi Terrane (Fig. 13b). 

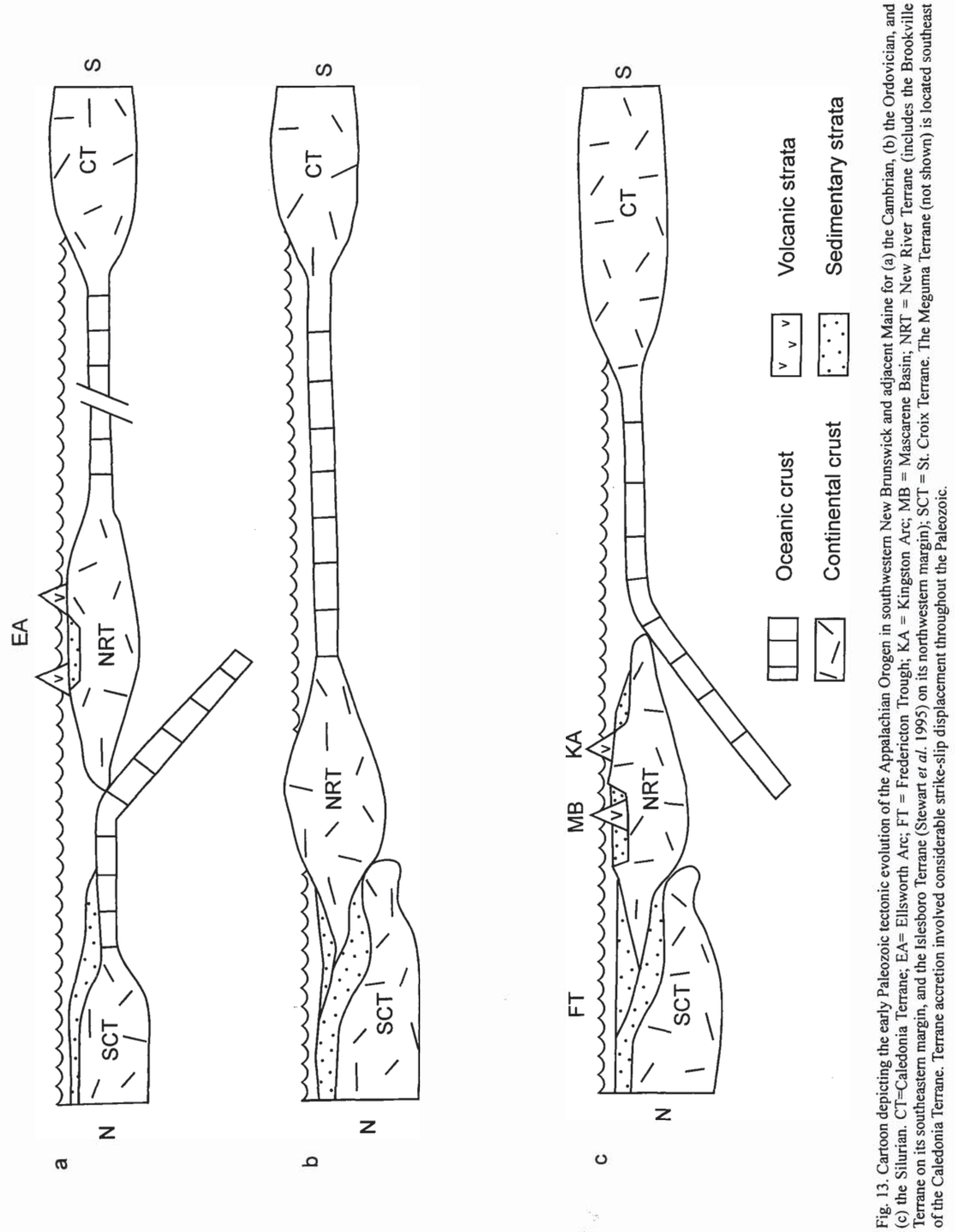
The paleogeographic position of the St. Croix Terrane in a model having a subduction zone dippng southeasterly beneath the New River Terrane is equivocal; if originally part of the New River microplate, the St. Croix Terrane would have been located in the fore-arc region, but if part of the Miramichi plate, it would have been situated on a passive margin. The quartz-rich composition of the Cookson Group more closely resembles passive continental margin deposits (van Staal and Fyffe 1995) than those expected along an active margin. The cryptic suture is interpreted, therefore, to lie between the St. Croix and New River terranes rather than between the Miramichi and St. Croix terranes and would be marked by the Falls Brook Fault in the Oak Bay area (Fig. 1). A shift from a passive to an active margin may be reflected in the change in sedimentation in the Cookson Group. Thus quartz-rich beds and minor limestone at the base of the Early Ordovician Calais Formation pass into black shale at its top and hence into more feldspathic beds in the overlying Woodland Formation as detritus became available from erosion of the Cambrian Ellsworth Arc on the overriding New River plate (Fig. 13b). Early northwesterly verging isoclinal folds in the Cookson Group (Ludman 1991), prominent in the internal part of the St. Croix terrane but dying out toward the Fredericton Trough, are consistent with a major detachment zone lying to the southeast of the St. Croix Terrane. Younger tight upright folds that also affect strata of the overlying Silurian Flume Ridge Formation of the Fredericton Trough (but not the homoclinal sequences of the Oak Bay and Waweig formations of the Mascarene Basin) are likely related to collision of the Ganderian Miramichi and St. Croix terranes with the Laurentian margin (van Staal and Fyffe 1995).

We agree with Ludman et al. (1993) that the volcanic and high-level plutonic clasts in the coarse, lithic sandstone of the Digdeguash Formation, marking the transitional boundary between the St. Croix Terrane and Fredericton Trough, were likely derived from the uplifted New River Terrane. However, we would contend that this uplift occurred in the Ordovician (Fig. 13b), not in the Late Silurian as advocated by Ludman et al. (1993). Our premise is based on the observation that the Digdeguash Formation gradationally overlies the graptolitebearing, early Caradocian Kendall Mountain Formation and, therefore, could reasonably be as old as late Caradocian and likely not younger than Ashgillian (Fyffe and Miller 1992).

Paleontological evidence indicates that carbonate deposition and calc-alkaline, arc-related volcanism in the Goss Point Formation of the Mascarene Basin (Johnson and McLeod 1996) began in the Ashgillian (or slightly earlier) and overlapped in time with the calcareous sedimentation in the Flume Ridge Formation of the Fredericton Trough (Fig. 13c). Along strike to the northeast on the Kingston Peninsula, Early Silurian volcanic rocks of the Bayswater Group and associated mafic dykes possess arc-like trace-element signatures (Eby and Currie 1993; Barr et al. 1997) We consider this initially largely subaerial volcanic block to be the eroded remains of an ensialic arc and refer to it as the Kingston Arc. This arc underwent extension accompanied by sinistral strike-slip faulting beginning in the late Llandoverian with the extrusion of thick mafic pillow lavas and emplacement of abundant feeder dykes (Cutler Diabase) into the Quoddy Formation (Gates 1961), and emplacement of a mafic dyke swarm into the Bayswater Group of the Kingston Peninsula area (Doig et al. 1990). Both the Bayswater Group and the conformably overlying Quoddy Formation are considered here to be part of the rifted Kingston Arc (Fig. 1).

We would contend that the stratigraphic and sedimentological evidence connects the Oak Bay-Waweig succession to the development of the Kingston Arc and Mascarene Basin rather than to that of the Fredericton Trough, in contradistinction to Ruitenberg (1967) and Ruitenberg and Ludman (1978). The present distribution of the volcaniclastic strata of the Mascarene Basin exhibits an asymmetric age pattern across the various fault blocks in southwestern New Brunswick and adjacent Maine (Figs. 1, 4). This pattern, with oldest rocks preserved in the Goss Point and Back Bay formations and apparent progressively younger basal beds in the Addison and Oak Bay conglomerates, suggests a sequential development of the basin by progressive block faulting from the southeast to the northwest. This block faulting can reasonably be attributed to rifting of the Kingston Arc and development of an associated back-arc basin (Fig. 13c). In this interpretation, the arc-like volcanic sequence of the Goss Point Formation represents a rifted remnant of the Kingston Arc preserved within the Mascarene Basin.

The presence of a back-arc basin to the northwest of the Kingston Arc is consistent with the intraplate character of the Silurian to Early Devonian volcanic rocks in coastal Maine and adjacent New Brunswick (Gates and Moench 1981; Baldwin 1991). The intraplate tholeiitic signature of the Waweig Formation (Fyffe, unpublished data) indicates that back-arc rifting had propagated northwestward into the highlands of the St. Croix Terrane by the Late Silurian (late Ludlovian) (Fig. 13c). It is conceivable that many of the igneous pebbles in the Oak Bay Formation were derived from intrabasinal erosion of older arc edifices located to the southeast of the Back Bay Fault.

Subbasin architecture can be complex in arc and back-arc settings (Stratford and Aitchison 1996; Sowerbutts and Underhill 1998; Fackler-Adams and Busby 1998) and may account for the variety of facies observed on the different fault blocks of the Mascarene Basin. Back-arc extension presumably took place in a transtensional setting because bounding faults such as the Turtle Head exhibit evidence of Silurian strike-slip displacement (Stewart et al. 1995). Subsequent folding of the southeastern portions of the basin was accompanied by a significant high-angle reverse component of displacement on the St. George, Back Bay, and Lubec faults (cf. Brown and Helmstaedt 1970; Brown 1972; Gates 1977; Donohoe 1978). This inversion and juxtaposition of the polydeformed sequences to the southeast (Goss Point, Back Bay and Letete formations) against mainly gently to moderately inclined sequences to the northwest (Oak Bay and Waweig formations and Coastal Maine sequence) are interpreted as a consequence of oblique collision of the periGondwanan New River and Caledonia terranes. Convergence took place along a northwesterly dipping subduction zone as indicated by the spatial relationship of the Kingston Arc (Bayswater Group, Quoddy Formation) to the back-arc Mascarene Basin (Figs. 1, 13c). Amalgamation of the New River (including Brookville) and Caledonia terranes occurred between the Late Silurian and Early Devonian as indicated by 
their shared tectonothermal history (Dallmeyer and Nance 1994). Gently dipping conglomerate of the Late Devonian Perry Formation rests unconformably on the deformed strata of the Mascarene Basin (Donohoe and Pajari 1973).

Northeasterly trending faults in the northwestern part of the Mascarene Basin were largely inactive by the Early Devonian since they have been truncated by undeformed plutonic rocks of that age (West et al. 1992). However, movement on northeasterly trending faults to the southeast continued into the Late Devonian and Carboniferous. This largely dextral strike-slip displacement (Léger and Williams 1986; Park et al. 1994) was presumably related to oblique collision between the Caledonia Terrane of southeastern New Brunswick and the Meguma Terrane of Nova Scotia (Poole 1976; Keen et al. 1991; Keppie et al. 1997; van Staal et al. 1998). Thrusting on the St. George Fault, associated with the strike-slip movement, locally placed strata of the Eastport Formation over those of the Perry Formation on the northwestern tip of the Mascarene Peninsula (Donohoe 1978; Fig. 1).

\section{ACKNOWLEDGEMENTS}

We wish to acknowledge the contributions that Dick Brown, George Pajari, Nick Rast, and Paul Williams and their students have made toward improving the understanding of the geological history of southwestern New Brunswick. Discussions and field trips with Sandra Barr, Ken Currie, Ollie Gates, Sue Johnson, Allan Ludman, Malcolm McLeod, Damian Nance, Phil Osberg, Art Ruitenberg, Dave Stewart, Clinton St. Peter, and Cees van Staal have been useful in formulating some of the ideas presented in this paper. Dave Stevens of St. Andrews showed us one of the fossil sites on Route 127. Terry Leonard and Bob McCulloch prepared the figures. Cees van Staal and Chris White are thanked for their thoughtful reviews.

We dedicate this paper to the memory of the late Ollie Gates, who passed away in the summer of 1999 , for his outstanding contributions to the geology of northeastern Maine and southwestern New Brunswick.

ABBOTT, R.N. 1991. Relationships between intrusive rocks in the Robbinston 15' Quadrangle, Maine. In Geology of the Coastal Lithotectonic Block and Neighboring Terranes, Eastern Maine and Southern New Brunswick. Edited by A Ludman. 83 Annual Meeting, New England Intercollegiate Geological Conference, Field Guide, pp. 133-156.

AMOS, D.H. 1963. Petrology and age of plutonic rocks, extreme southeastern Maine. Geological Society of America, Bulletin, 74, pp. 169-194.

Balley, L.W. and MATTHEW, G.F. 1872. Preliminary report on the geology of southern New Brunswick. Geological Survey of Canada, Report of Progress for 1870-71, Part 2, pp. 13-240.

BALDWIN, D.K. 1991. Physical vólcanology, geochemistry, and depositional setting of Siluro-Devonian volcanic rocks near St. Andrews, New Brunswick. Unpublished M.Sc. thesis, Acadia University, Wolfville, Nova Scotia, 23lp.

BARR, S.M. and WHITE, C.E. 1996. Contrasts in late Precambrianearly Paleozoic tectonothermal history between Avalon composite terrane sensu stricto and other possible periGondwanan terranes in southern New Brunswick and Cape Breton Island, Canada. In Avalonian and Related Peri-
Gondwanan Terranes of the Circum-North Atlantic. Edited by R.D. Nance and M.D. Thompson. Geological Society of America, Special Paper 304, pp. 95-108.

BARR, S.M., WHITE, C.E., and MCLEOD, M.J. 1997. Geology of the Kingston Peninsula, southern New Brunswick: a preliminary report. In Current Research 1996. Edited by B.M.W. Carroll. New Brunswick Department of Natural Resources and Energy, Minerals and Energy Division, Mineral Resource Report 97-4, pp. 1-20.

BAStin, E.S. and Williams, H.S. 1914. Eastport Folio, Maine: Geologic Atlas of the United States. U.S. Geological Survey, Folio 192, $15 \mathrm{p}$.

BERDAN, J.M. 1971. Silurian to Early Devonian ostracodes of European aspect from the Eastport Quadrangle, Maine. Geological Society of America, Abstracts with Programs, 3, No. 1, p. 18.

BOUCOT, A.J., JOHNSON, J.G., HARPER, C., and WALMSLEY, V.G. 1966. Silurian brachiopods and gastropods of southern New Brunswick. Geological Survey of Canada, Bulletin 140, 45 p.

BoumA, A.H. 1962. Sedimentology of Some Flysch Deposits. Elsevier, Amsterdam, $168 \mathrm{p}$.

BRADLEY, D.C. 1983. Tectonics of the Acadian Orogeny in New England and adjacent Canada. Journal of Geology, 91, pp. 381400.

BROWN, R.L. 1972. Appalachian structural style in southern New Brunswick. Canadian Journal of Earth Sciences, 9, pp. 43-53.

BROWN, R.L. and HELMSTAEDT, H. 1970. Deformation history in part of the Lubec-Belleisle zone of southern New Brunswick. Canadian Journal of Earth Sciences, 7, pp. 748-767.

BURKE, K.B.S. and STRINGER, P. 1993. A search for neotectonic features in the Passamaquoddy Bay region, southwestern New Brunswick. In Current Research, Part D. Geological Survey of Canada, Paper 93-1D, pp. 93-102.

CuMMING, L.M. 1966. Geology of the Passamaquoddy Bay region, Charlotte County, New Brunswick. Geological Survey of Canada, Paper 65-29, 36 p.

CURRIE, K.L. 1988. The western end of the Avalon zone in southern New Brunswick. Maritime Sediments and Atlantic Geology, 24, pp. 339-352.

DALLMEYER, R.D. and NANCE, R.D. 1994. ${ }^{40} \mathrm{Ar} /{ }^{39} \mathrm{Ar}$ whole-rock phyllite ages from late Precambrian rocks of the Avalon composite terrane, New Brunswick: evidence of SilurianDevonian thermal rejuvenation. Canadian Joumal of Earth Sciences, 31, pp. 818-824.

DoIG, R., Nance, R.D., MurPhy, J.B., and CASSEDaY, R.P. 1990. Evidence for Silurian sinistral accretion of Avalon terrane in Canada. Journal of the Geological Society, London, 147, pp. 927-930.

DONOHOE, H.V., JR. 1973. Acadian orogeny in coastal New Brunswick. In Geology of New Brunswick. Edited by N. Rast. New England Intercollegiate Geological Conference, Field Guide to Excursions, pp. 71-80.

1978. Analysis of structures in the St. George area, Charlotte County, New Brunswick. Unpublished Ph.D. thesis, University of New Brunswick, Fredericton, New Brunswick, 227 p.

DONOHOE, H.V., JR. and PAJARI, G. 1973. The age of the Acadian deformation in Maine-New Brunswick. Maritime Sediments, 9, pp. 78-82.

EBY, G.N. and CURRIE, K.L. 1993. Petrology and geochemistry of the Kingston complex - a bimodal sheeted dyke suite in southern New Brunswick. Atlantic Geology, 29, pp. 121-135.

FARQuHARSON, G.W., HAMER, R.D., and INESON, J.R. 1984. Proximal volcaniclastic sedimentation in a Cretaceous back-arc basin, northern Antarctic Peninsula. In Marginal Basin Geology. Edited by B.P. Kokelaar and M.F. Howells. Geological Society, London, Special Publication 16, pp. 219-229.

FACKLER-ADAMS, B.M. and BUSBY, C.J. 1998. Structural and 
stratigraphic evolution of extensional oceanic arcs. Geology, 26, pp. 735-738.

FYFFE, L.R. 1991. Geology of the Tower Hill area (NTS 21/G6b), Charlotte County, New Brunswick. New Brunswick Department of Natural Resources, Minerals and Energy Division, Plate 9135 .

1997a. Geology of the Sorrel Ridge area (NTS 21/G6a), Charlotte County, New Brunswick. New Brunswick Department of Natural Resources, Minerals and Energy Division, Plate 97-5.

1997b. Geology of the Oak Bay area (NTS 21/G/3g), Charlotte County, New Brunswick. New Brunswick Department of Natural Resources, Minerals and Energy Division, Plate 9732.

FYFFE, L.R. and FRICKER, A. 1987. Tectonostratigraphic terrane analysis of New Brunswick. Maritime Sediments and Atlantic Geology, 23, pp. 113-123.

FYFFE, L.R. and MILLER, R.F. 1992. A note on reported plant fossils from the Flume Ridge area of southwestern New Brunswick. Atlantic Geology, 28, pp. 215-220.

FYFFE, L.R., MCLEOD, M.J., and RUITENBERG, A.A. 1992. A geotraverse across the St. Croix-Avalon terrane boundary, southern New Brunswick. Geological Association of Canada, Mineralogical Association of Canada, Joint Annual Meeting, Wolfville '92, Field Trip A 1, Guidebook, 44 p.

GATES, O. 1961. The geology of the Cutler and Moose River quadrangles, Washington County, Maine. Maine Geological Survey, Quadrangle Mapping Series No. 1, 67 p.

_ 1969. Lower Silurian-Lower Devonian volcanic rocks of New England coast and southern New Brunswick. In North Atlantic - Geology and Continental Drift. Edited by M. Kay. American Association of Petroleum Geologists, Memoir 12, pp. 484-503.

- 1975. Geologic map and cross sections of the Eastport Quadrangle, Maine. Maine Geological Survey, Geological Map Series GM-3.

- 1977. Notes to accompany Geological Map Series GM-3, Washington County, Maine Geological Survey, 19 p.

- 1982. Preliminary bedrock and brittle fracture map of the Eastport $2^{\circ}$ Sheet, Maine. Maine Geological Survey, Open File 82-29.

1989. Silurian roundstone conglomerates of coastal Maine and adjacent New Brunswick. In Studies in Maine Geology, Volume 2: Structure and Stratigraphy. Edited by R.D. Tucker and R.G. Marvinney. Maine Geological Survey, pp. 127-144.

GATES, O. and MOENCH, R.H. 1981. Bimodal Silurian and Lower Devonian volcanic rock assemblages in the Machias-Eastport area, Maine. U.S. Geological Survey, Professional Paper 1184, $32 \mathrm{p}$.

GiLmAN, R.A. 1966. Silurian subaqueous slide conglomerate, Addison, Maine. Maine Geological Survey, Bulletin 18, pp. 6477.

GREenOUGH, J.D., MCCUTCHEON, S.R., and PAPEZIK, V.S. 1985. Petrology and geochemistry of Cambrian volcanic rocks from the Avalon Zone in New Brunswick. Canadian Journal of Earth Sciences, 22, pp. 881-892.

HAMPTON, M.A. 1972. The role of subaqueous debris flow in generating turbidity currents. Journal of Sedimentary Petrology, 42, pp. 775-793.

HAY, P.W. 1967. Sedimentary and volcanic rocks of the St. AndrewsSt. George area, Charlotte County, New Brunswick. Department of Natural Resources, Mineral Resources Branch, New Brunswick, Map Series 67-1, 19 p.

Johnson, S.C. and MCLEOD, M.J. 1996. The New River Belt: a unique segment along the western margin of the Avalon composite terrane, southern New Brunswick, Canada. In Avalonian and Related Peri-Gondwanan Terranes of the CircumNorth Atlantic. Edited by R.D. Nance and M.D. Thompson.
Geological Society of America, Special Paper 304, pp. 149-164. KeEn, C.E., KaY, W.A., KePpie, D., Marillier, F., PE-PIPER, G., and WALDRON, J.W.F. 1991. Deep seismic reflection data from the Bay of Fundy and Gulf of Maine: tectonic implications for the northern Appalachians. Canadian Journal of Earth Sciences, 28, pp. 1096-1111.

Keppie, J.D., Dostal, J., Murphy, B., and Cousens, B.L. 1997. Palaeozoic within-plate volcanic rocks in Nova Scotia (Canada) reinterpreted: isotopic constraints on magmatic source and palaeocontinental reconstructions. Geological Magazine, 134, pp. 425-447.

LANDING, E., Bowring, S.A , DAVIDEK, K.L., Westrop, S.R., GeYer, G., and Heldmaier, W. 1998. Duration of the Early Cambrian: $\mathrm{U}-\mathrm{Pb}$ ages of volcanic ashes from Avalon and Gondwana. Canadian Journal of Earth Sciences, 35, pp. 329 . 338.

LÉGER, A. and WILLIAMS, P.F. 1986. Transcurrent faulting history of southern New Brunswick. In Current Research, Part B. Geological Survey of Canada, Paper 86-1B, pp. 111-120.

LONSDALE, P.S. 1975. Sedimentation and tectonic modification of Samoan archipelagic apron. American Association of Petroleum Geologists, Bulletin, 59, pp. 780-798.

LOWE, D.R. 1982. Sediment gravity flows: II. Depositional models with special reference to the deposits of high-density turbidity currents. Journal of Sedimentary Petrology, 52, pp. 279-297.

LUDMAN, A. 1987. Pre-Silurian stratigraphy and tectonic significance of the St. Croix Belt, southeastern Maine. Canadian Journal of Earth Sciences, 24, pp. 2459-2469.

1991. Revised stratigraphy of the Cookson Group in eastern Maine and southwestern New Brunswick: an alternate view. Atlantic Geology, 27, pp. 49-55.

LUdMAN, A., HopeCK, J.T., and BROCK, P.C. 1993. Nature of the Acadian orogeny in eastern Maine. In The Acadian Orogeny: Recent Studies in New England, Maritime Canada, and the Autochthonous Foreland. Edited by D.C. Roy and J.S. Skehan. Geological Society of America, Special Paper 275, pp. 67-84.

MacKenzIE, G.S. 1940. The St. Stephen map-area, Charlotte County, New Brunswick. New Brunswick Department of Lands and Mines, Mining Section, Paper 40-6, 46 p.

MACKenZIE, G.S. and ALCOCK, F.J. 1960a. Geology of Rolling Dam, Charlotte County, New Brunswick. Geological Survey of Canada, Map 1097A.

- 1960b. Geology of St. Stephen, Charlotte County, New Brunswick. Geological Survey of Canada, Map 1096A.

MCKerRow, W.S. and ZIEGLER, A.M. 1971. The Lower Silurian paleogeography of New Brunswick and adjacent areas. Journal of Geology, 79, pp. 635-646.

MCLEOD, M.J. 1990. Geology, geochemistry, and related mineral deposits of the Saint George Batholith; Charlotte, Queens, and Kings counties, New Brunswick. New Brunswick Department of Natural Resources and Energy, Mineral Resource Report 5, 169 p.

MCLEOD, M.J. and RAST, N. 1988. Correlations and fault systematics in the Passamaquoddy Bay area, southwestern New Brunswick. Maritime Sediments and Atlantic Geology, 24, pp. 289-300.

MCLEOD, M.J., RUITENBERG, A.A., and KROGH, T.E. 1992. Geology and $\mathrm{U}-\mathrm{Pb}$ geochronology of the Annidale Group, southern New Brunswick: Lower Ordovician volcanic and sedimentary rocks formed near the southeastern margin of Iapetus Ocean. Atlantic Geology, 28, pp. 181-192.

MCLEOD, M.J., WINCheSter, J. A., and RuItEnBERG, A.A. 1994. Geochemistry of the Annidale Group: implications for the tectonic setting of the Lower Ordovician volcanism in southwestern New Brunswick. Atlantic Geology, 30, pp. 87-95.

NANCE, R.D. 1987. Model for the Precambrian evolution of the Avalon terrane in southern New Brunswick. Geology, 15, pp. 753-756. 
NANCE, R.D. and DALLMEYER, R.D. $1993 .{ }^{40} \mathrm{Ar} /{ }^{39} \mathrm{Ar}$ amphibole ages from the Kingston complex, New Brunswick: evidence for Silurian-Devonian tectonothermal activity and implications for the accretion of the Avalon composite terrane. Journal of Geology, 101, pp. 375-388.

1994. Structural and ${ }^{40} \mathrm{Ar} /{ }^{39} \mathrm{Ar}$ mineral age constraints for the tectonothermal evolution of the Green Head Group and Brookville Gneiss, southern New Brunswick, Canada: implications for the configuration of the Avalon composite terrane. Geological Journal, 29, pp. 293-322.

Nowlan, G.S., MCCraCKen, A.D., and MCLeOD, M.J. 1997. Tectonic and paleogeographic significance of Late Ordovician conodonts in the Canadian Appalachians. Canadian Journal of Earth Sciences, 34, pp. 1521-1537.

OSBERG, P.H. 1968. Stratigraphy, structural geology, and metamorphism of the Waterford-Vassalboro area, Maine. Maine Geological Survey, Bulletin 20,64 p.

Park, A.F., Williams, P.F., RAlSer, S., and LEGER, A. 1994. Geometry and kinematics of a major crustal shear zone segment in the Appalachians of southern New Brunswick. Canadian Journal of Earth Sciences, 31, pp. 1523-1535.

PICKERILL, R.K. 1976. Significance of a new fossil locality containing a Salopina community in the Waweig Formation (Silurian-uppermost Ludlow/Pridoli) of southwest New Brunswick. Canadian Journal of Earth Sciences, 13, pp. 13281331.

PICKERILL, R.K. and PAJARI, G.E., JR. 1976. The Eastport Formation (Lower Devonian) in the northern Passamaquoddy Bay area, southwest New Brunswick. Canadian Joumal of Earth Sciences, 13, pp. 266-270.

PICKERILL, R.K., PAJARI, G.E., and DiCKSON, W.L. 1978. Geology of the Lower Devonian rocks of Passamaquoddy Bay, southwest New Brunswick. In Guidebook for Field Trips in Southeastern Maine and Southwestern New Brunswick. Edited by A. Ludman. 70th Annual Meeting, New England Intercollegiate Geological Conference, pp. 38-56.

PICKERING, K.T., StOW, D.A.V., WATSON, M.P., and HiscotT, R.N. 1986. Deep-water facies, processes and models: a review and classification scheme for modern and ancient sediments. EarthScience Reviews, 23, pp. 75-174.

Poole, W.H. 1976. Plate tectonic evolution of the Canadian Appalachian region. Geological Survey of Canada, Paper 76-1B, pp. 113-126.

RAST, N. 1979. Precambrian meta-diabases of southern New Brunswick - the opening of the Iapetus ocean? Tectonophysics, 59, pp. 127-137.

RAST, N. and DicKSON, W.L. 1982. The Pocologan mylonite zone. In Major Structural Zones and Faults of the Northern Appalachians. Edited by P. St-Julien and J. Béland. Geological Association of Canada, Special Paper 24, pp. 249-261.

RUITENBERG, A.A. 1967. Stratigraphy, structure and metallization, Piskahegan-Rolling Dam area, northern Appalachians, New Brunswick, Canada. Leidse Geologische Mededelingen, 40, pp. 79-120.

1968. Geology and mineral deposits, Passamaquoddy Bay area. New Brunswick Department of Natural Resources, Mineral Resources Branch, Report of Investigation 7, $47 \mathrm{p}$.

- 1972. Metallization episodes related to tectonic evolution, Rolling Dam and Mascarene-Nerepis belts, New Brunswick. Economic Geology, 67, pp. 434-444.

RUITENBERG, A.A. and LUDMAN, A. 1978. Stratigraphy and tectonic setting of Early Paleozoic sedimentary rocks of the Wirral-Big Lake area, southwestern New Brunswick and southeastern Maine. Canadian Journal of Earth Sciences, 15, pp. 22-32.

SCHMID, R. 1981. Descriptive nomenclature and classification of pyroclastic deposits and fragments: recommendations of the IUGS Subcommission on the Systematics of Igneous Rocks.
Geology, 9, pp. 41-43.

Sigurdsson, H., Sparks, R.S.J., Carey, S.N., and Huang, T.C. 1980. Volcanogenic sedimentation in the Lesser Antilles arc. Journal of Geology, 88, pp. 523-540.

SOWERBUTTS, A.A. and UNDERHILL, J.R. 1998. Sedimentary response to intra-arc extension: controls on Oligo-Miocene deposition, Sarcidano sub-basin, Sardinia. Journal of the Geological Society, London, 155, pp. 491-508.

STRATFORD, J.M.C. and AITCHISON, J.C. 1995. Devonian intraoceanic arc rift sedimentation-facies development in the Gamilaroi terrane, New England orogen, eastern Australia. Sedimentary Geology, 101, pp.173-192.

STEWART, D.B., UNGER, J.D., and HuTCHINSON, D.R. 1995. Silurian tectonic history of Penobscot Bay region, Maine. Atlantic Geology, 31, pp. 67-79.

STRINGER, P. 1982. Polyorogenic deformation in coastal southern N.B., Field Trip Guidebook 'H'. The Caledonide Orogen, IGCP Project 27, NATO Advanced Study Institute, Atlantic Canada, $15 \mathrm{p}$.

StRINGER, P. and BURKE, K.B.S. 1985. Structure in southwest New Brunswick, Excursion 9. In "Fredericton 85" Field Excursions, Volume III. Edited by R.K. Pickerill, C.K. Mawer and L.R. Fyffe. Geological Association of Canada, Mineralogical Association of Canada, University of New Brunswick, Fredericton, New Brunswick, pp. 1-34.

StrInger, P. and PAJARI, G.E., Jr. 1982. Deformation of Ordovician and Silurian rocks at Oak Bay and Cookson Island, St. Stephen, New Brunswick (Abstract). Journal of Structural Geology, 4, pp. 234-235.

StrINGER, P., BURKE, K.B.S., and DUNN, T. 1991. Stratigraphy, structure and associated igneous rocks of the Upper Devonian Perry Formation in the St. Andrews area, southwest New Brunswick, and adjacent coastal Maine. In Geology of the Coastal Lithotectonic Block and Neighboring Terranes, Eastern Maine and Southern New Brunswick. Edited by A. Ludman. $83^{\text {rd }}$ Annual Meeting, New England Intercollegiate Geological Conference, Field Guide, pp. 222-264.

ThOMAS, M.D. and WILlis, C. 1989. Gravity modelling of the Saint George Batholith and adjacent terrane within the Appalachian Orogen, southern New Brunswick. Canadian Journal of Earth Sciences, 26, pp. 561-576.

TUCKER, R.D. and MCKerRow, W.S. 1995. Early Paleozoic chronology: a review in light of new U-Pb zircon ages from Newfoundland and Britain. Canadian Journal of Earth Sciences, 32, pp. 368-379.

TuCKer, R.D., Bradley, D.C., Ver Straeten, C.A., Harris, A.G., EBERT, J.R., and MCCUTCHEON, S.R. 1998. New U-Pb zircon ages and the duration and division of Devonian time. Earth and Planetary Science Letters, 158, pp. 175-186.

VAN STAAL, C.R. and FYFFE, L.R. 1995. Gander Zone-New Brunswick. In Geology of the Appalachian-Caledonian Orogen in Canada and Greenland. Edited by H. Williams. Geological Survey of Canada, Geology of Canada, No. 6, pp. 216-223.

van StaAl, C.R., Sullivan, R.W., and Whalen, J.B. 1996. Provenance and tectonic history of the Gander Zone in the Caledonian/Appalachian orogen: implications for the origin and assembly of Avalon. In Avalonian and Related Peri-Gondwanan Terranes of the Circum-North Atlantic. Edited by R.D. Nance and M.D. Thompson. Geological Society of America, Special Paper 304, pp. 347-367.

VAN StAAL, C.R., DEWEY, J.F., MACNIOCAILl, C., and MCKerRow, W.S. 1998. The Cambrian-Silurian tectonic evolution of the northern Appalachians and British Caledonides: history of a complex, west and southwest Pacific-type segment of Iapetus. In Lyell, The Past is the Key to the Present. Edited by D.J. Blundell and A.C. Scott. Geological Society, London, Special Publication, 143, pp. 199-242. 
VAN WAGONER, N.A., MCNEIL, W., and FAY, V.K. 1988. Early Devonian bimodal volcanic rocks of southwestern New Brunswick: petrography, stratigraphy, and depositional setting. Maritime Sediments and Atlantic Geology, 24, pp. 301-319.

VAN WAGONER, N.A., DADD, K.A., BALDWIN, D.K., and MCNEI, W. 1994. Physical volcanology, stratigraphy, and depositional setting of the Middle Paleozoic volcanic and sedimentary rocks of Passamaquoddy Bay, southwestern New Brunswick. Geological Survey of Canada, Paper 91-14, 46 p.

WATKINS, R. and BouCOT, A.J. 1975. Evolution of Silurian brachiopod communities along the southeastern coast of Acadia. Geological Society of America, Bulletin, 86, pp. 243-254.

WeBB, G.W. 1969. Paleozoic wrench faults in Canadian Appalachians. In North Atlantic-Geology and Continental Drift. Edited by M. Kay. American Association of Petroleum Geologists, Memoir 12, pp. 754-788.

West, D.P., JR., LUDMAN, A., and LUX, D.R. 1992. Silurian age for the Pocomoonshine gabbro-diorite, southeastern Maine and its regional tectonic implications. American Joumal of Science, 292, pp. 253-273.

WESTERMAN, D.S. 1978. Bedrock geology of the Wesley Quadrangle. In Guidebook for Field Trips in Southeastern Maine and Southwestern New Brunswick. Edited by A. Ludman. 70th Annual Meeting, New England Intercollegiate Geological
Conference, pp. 120-132.

1979. Plutonic rocks in Washington County, Maine. The Maine Geologist, 5, No. 3, pp. 4-5.

1981. Reconnaissance bedrock geology of the Wesley 15' Quadrangle, Maine. Maine Geological Survey, Open File 81-90.

Williams, H. and HATCHER, R.D., Jr. 1982. Suspect terranes and accretionary history of the Appalachian orogen. Geology, 10, pp. 530-536.

WilliaMS, P. F. and HY, C. 1990. Origin and deformational and metamorphic history of gold-bearing quartz veins on the Eastern Shore of Nova Scotia. In Mineral Deposits Studies in Nova Scotia, Volume 1. Edited by A. L. Sangster. Geological Survey of Canada, Paper 90-8, pp. 169-194.

Williams, P.F., Goodwin, L.B., and LaFrance, B. 1995. Brittle faulting in the Canadian Appalachians and the interpretation of reflection seismic data. Journal of Structural Geology, 17, pp. 215-232.

WRIGHT, J.V. and MutTI, E. 1981. The Dali Ash, Island of Rhodes, Greece: a problem in interpreting submarine volcanigenic sediments. Bulletin of Volcanology, 44, pp. 153-167.

Editorial responsibility: S.M. Barr 